\title{
Preventive Factors of Postpartum Depression in Adult Mothers: A Systematic Review of Randomized Controlled Trials
}

Nura Mahmalat ( $\square$ nura.mahmalat@uni-wh.de)

Universitat Witten/Herdecke https://orcid.org/0000-0002-1380-3801

Thomas Ostermann

Universitat Witten/Herdecke

Katharina Fetz

Universitat Witten/Herdecke

\section{Research article}

Keywords: postpartum depression, postnatal, prevention, systematic review

Posted Date: June 22nd, 2020

DOI: https://doi.org/10.21203/rs.3.rs-36611/v1

License: () (i) This work is licensed under a Creative Commons Attribution 4.0 International License. Read Full License 


\section{Abstract}

Background: Postpartum Depression (PPD) is defined as major depressive disorder with peripartum onset. It is the most common mental illness that occurs after childbirth, affecting not only mother but also newborn. Considering the great impact PPD has, it is relevant to investigate the effectiveness of preventive interventions.

Objective: This review investigates published literature of the last decade (2009-2019) regarding the topic of preventive factors of PPD in adult mothers.

Methods: An electronic search was conducted by using PubMed, psycINFO and Google Scholar. The search term included a combination of postpartum depression, postnatal depression, predictor, prevention and risk factor. Inclusion criteria were: 1) randomized controlled trials (RCT) published in English or German language that deal with 2 ) adult pregnant or adult mothers (>18 years). Extraction of articles by two independent raters using predefined data fields, including study quality indicators.

Results: The electronic search resulted in a total of 905 articles, whereby only 22 articles were relevant for this synthesis. The interventions were divided into five major topics, these being psychological, psychosocial, nutritional, medical, and exercise interventions. Significant preventive effects concerning PPD in adult mothers were found in psychological and psychosocial interventions. Nutritional, medical and exercise interventions did not have a significant preventive impact.

Conclusion: Psychological and psychosocial interventions seem to be effective in the prevention of PPD. Consequently, preventive programs should include such components. Implications for future research might include the comparison of already existing prevention programs for PPD and the observation of their long-term effects.

\section{Introduction}

Postpartum depression (PPD) is the most common mental illness that occurs after childbirth [1]. The Diagnostic and Statistical Manual of Mental Disorders does not define it as an independent diagnosis, but rather as a major depressive disorder "with peripartum onset" [2]. A major depressive disorder may include the following diagnostic criteria: depressed mood, loss of pleasure, change of body weight, insomnia or hypersomnia, psychomotor agitation, fatigue, feelings of worthlessness, concentration difficulties, suicidal thoughts [2]. The time criterion refers to the time "during pregnancy or four weeks postpartum" [2].

The terms postnatal depression and postpartum depression are frequently used interchangeably, but they do not mean the same: postnatal describes the time after birth, related to the child, whereas postpartum refers to the period after giving birth, in relation to the mother [3]. The medically correct term is postpartum depression, accordingly we only refer to a major depressive disorder with peripartum onset as postpartum depression (PPD). However, we included studies in this review that used the term postnatal depression [4-8].

The most common differential diagnosis is the so called Baby Blues or Postpartum Blues [9]. It occurs around the 2nd and 5th day after delivery and is marked by a greater irritability of the mother and unexpected mood changes. The incidence of Baby Blues is very high, with approximately $17-80 \%$ of newly delivered mothers being affected by it [9].

Estimations of the prevalence of PPD vary strongly, mostly ranging from 10-15\% regarding western developed countries [10] or from 13-19\% as an overall prevalence [11]. In Germany, the prevalence for PDD was 3.6\% in the year 2005 [12], newer studies have estimated a total of 70,000 mothers that are affected every year [10]. However, a meta-analysis showed a range from almost $0-60 \%$ in 40 countries. The authors state that the frequently cited rate of $10-15 \%$ is too low and is therefore not representative of the global prevalence rate of PPD [13].

PPD affects not only the mother but also the newborn. Researchers have found a negative correlation between depression and breastfeeding [14]. This implies that the numerous health benefits of breastfeeding for mother and child and the promoted bonding are at risk because of maternal depression [15]. Moreover, infants of depressed mothers are at risk for negative emotional development, e.g. disturbance in self-regulation [16].

In a study conducted with 360 pregnant women, Gotlib et al. [17] found out, that $25 \%$ of the sample had higher depressive outcomes, $10 \%$ depression during pregnancy and $6.8 \%$ were depressed postpartum. Yet out of these only $3.4 \%$ were new onset. It has been established that psychiatric history is the strongest predictor of PPD $[18,19]$. Werner et al. [19] summarized 15 risk factors for PPD, supporting the hypothesis that a history of depression is decisive for the development of PPD:

(1) lower social class, (2) life stressors during pregnancy, (3) complicated pregnancy/birth, (4) difficult relationship with family or partner, (5) lack of support from family or friends, (6) prior history of psychopathology (depression, anxiety), (7) chronic stressors postpartum (this can include problems with child care and difficult infant temperament), (8) unemployment/instability, (9) unplanned pregnancy, (10) ambivalence over becoming a pregnant, (11) poor relationship with own mother, (12) history of sexual abuse, (13) lack of a confidante, (14) bottle feeding, and (15) depression during pregnancy, with the last generally acknowledged to be the strongest predictor of PPD [19].

These are only some of the reasons why an early approach to prevent PPD is so beneficial. PPD has extensive influencing factors. Given the relevance of PPD, there are already reviews addressing the topic of preventive interventions of PPD [19,21]. Sangsawang et al [21] performed a systematic review regarding preventive interventions for PPD in adolescent mothers (10-19 years). They analyzed 13 published, English-language randomized controlled trials (RCT) with psychosocial and psychological intervention programs. They found that nearly half of the interventions had a significant effect in reducing PPD symptoms in adolescent mothers. Psychosocial interventions like home-visiting interventions, prenatal antenatal and postnatal education programs and infant massage training were effective; as well as psychological interventions including psycho-educational and cognitive behavioral therapy and group interpersonal therapy. 
Werner et al. [19] conducted a literature review regarding biological, psychological, and psychosocial preventive interventions for PPD. They analyzed 45 published, English-language RCTs. Out of those, 20 showed clear positive effects of an intervention. Among biological studies, the intake of calcium, sertraline and selenium had successful effects. Out of the psychological interventions interpersonal therapy, individual cognitive behavioral therapy (rather than groupbased interventions) and postnatal psychological debriefing found positive effects. Out of the psychosocial interventions only antenatal and postnatal classes were effective.

It is important to foster the research on the prevention of PPD, since it is a disease with serious impact on mother and child. The aim of this review is to provide a current overview on published RCTs investigating preventive factors for PPD. Different interventions designed to protect high risk as well as low risk pregnant and postpartum adult women in culturally diverse samples are investigated.

\section{Methods}

The systematic review was conducted in accordance with the Prisma guideline [22]. The search was applied to PubMed, psycINFO and Google Scholar. All articles published between the years 2009 to 2019 were considered. The following search term was used to search all databases:

((("postpartum depression" OR "postnatal depression") AND "predictor" [Title/Abstract]) OR ("postpartum depression" OR "postnatal depression") AND "prevention" [Title/Abstract]) OR (“postpartum depression" OR "postnatal depression”) AND "risk factor" [Title/Abstract]).

Primary outcome measures were depressive symptoms and major or minor depression with peripartum onset. No restrictions regarding types of intervention were imposed. The inclusion criteria were as following: (1) already published studies in English or German language; (2) studies involving human subjects; and (3) adult pregnant or adult mothers (>18 years). At the second step research designs other than RCT, such as non-comparative studies, qualitative studies, literature reviews, systematic reviews and meta-analyses, were excluded. Including only randomized studies ensured a reduction of bias and the integration of studies of a high-quality design.

Eligibility assessment was performed in an unblinded standardized manner by two independent raters (NM, KF). Disagreements were resolved by consensus between the two review authors (NM, KF); if no agreement could be reached, a third author was consulted (TO). All titles and abstracts were reviewed by NM to assess their eligibility. The eligibility of the included studies was checked by KF. Afterwards, the full texts from the eligible studies which report on risk and preventive factors of PPD were analyzed by NM and checked by KF.

The quality assessment tool Qualsyst [23] was used to evaluate the quality of the included studies. It includes 14 items, for example "Question/objective sufficiently described?" and "Study design evident and appropriate?" [23] (the remaining items are detailed in Table 1). Each of the items is scored on a 3-point Likert scale ("yes" = 2, "partial" = 1, "no" = 0), not applicable criteria are marked "n/a" [23]. For each paper a Qualsyst sum score and a percentage score was calculated. Criteria marked with "n/a" were excluded from both calculations. The quality classification was based on the percentage score: poor quality (score $<50 \%$ ), fair quality (score=50-69\%), good quality (score=70-79\%) and strong quality (score $>80 \%)$ [21].

The following information was extracted from the included studies: author(s), year of publication, study title, study design, sample characteristics (mean age, inclusion/exclusion criteria, sample size), type of intervention (including duration and frequency), control intervention, protective factors for PPD, outcome measures and findings. The structured approach commonly known by the acronym PICOS ("the patient population or the disease being addressed ( $P$ ), the interventions or exposure (I), the comparator group (C), the outcome or endpoint (0), and the study design chosen (S)" [24]) was used for the evaluation of results.

\section{Results}

\section{Search Results}

A total of 905 records were identified in the databases. After removing duplicates, 884 records were screened for relevance in protective factors for PPD based on titles and abstracts. 751 records were excluded based on not fitting content and 11 records were not available in the English or German language. No unpublished relevant studies were obtained. The remaining 153 records were screened for full text of which 106 records had a different study design than RCT, 9 records included participants under the age of 18, 8 records were study protocols, therefore not yet completed, and 8 records were thematically unfitting. This resulted in 22 records that met the inclusion criteria and were included in the systematic review (see Figure 1).

\section{Summary of quality assessment}

The results of the quality assessment with Qualsyst are presented in Table 1. None of the studies were classified as of poor quality. One study [25] was rated with fair quality (score $=50-69 \%$ ), two studies $[26,27]$ with good quality (score $=70-79 \%$ ) and 19 studies $[4-8,19,28-40]$ with strong quality (score $>80 \%$ ).

\section{Methods}

All studies finally selected for the review were RCTs published in English. The duration of the interventions varied strongly, with the shortest one being only one single session during which a drug was administered [39] and the longest being 12 months with a follow-up at 27 months [5].

\section{Participants}

The 22 included studies involved 10448 participants in total. Study sample sizes ranged from 27 to 2,241 participants. The main inclusion criteria were fulfilling certain age limits, if pregnant within determined weeks of gestation, having a history of depression/scoring a set baseline score on a depression 
instrument or having no depression at all.

Setting

The majority of the studies $(n=8)$ were conducted in the USA $[27,30,31,34,35,37,40,41]$, two in the UK $[4,28]$ and two in China [7, 39]. One study was conducted in each of the following countries: Canada [29], Mexico [33], Norway [8], Hungary [32], France [5], Iran [26], Australia [6], Denmark [36], South Africa [25], Brazil [38].

\section{Interventions}

In the reviewed studies, psychological $(n=7642)$, psychosocial $(n=1318)$, nutritional $(n=185)$, medical $(n=330)$ and exercise-based $(n=849)$ interventions were investigated. Table 2 provides an overview about the interventions and their effect. Out of the 22 studies 15 turned out to have a significant impact on the prevention of postpartum depression. 7 studies had no overall significant impact. In the following section the reviewed studies are reported in detail.

\section{Psychological interventions}

Lara et al. [33] conducted the first randomized control depression prevention trial on high-risk pregnant Mexican women. 138 adult pregnant women with $\leq 26$ weeks gestation and a baseline depression score on CES-D > 16 or a self-reported history of depression, took part in an 8-week prospective. The psychoeducational intervention included a manual that covered the following three components: educational (information on normal pregnancy and the postpartum period), psychological (aimed at reducing depression trough e.g. increasing positive thinking) and group component (atmosphere of support of facilitator). The control group received usual postpartum care. Primary outcome were major depression and depressive symptoms, anxiety symptoms as well as perceived intervention impact. There were significantly fewer new depression cases in the intervention group $(p<0.05)$. Repeated-measures analysis of variance found neither significant effects of treatment $(p=0.54)$ nor significant effects within group (time effect) $(p=0.00)$ and in the interaction of time by condition ( $p=0.02)$. Main effect for treatment and for initial CES-D level was significant $(p=0.54)$, but interaction between initial level of symptoms and treatment was not significant. Within groups significant effects of time $(p=0.00)$, interaction between time by initial level of depression $(p=0.00)$, time by treatment $(p=0.02)$, and time by treatment by initial level of depression $(p=0.04)$ were found.

Brugha et al. [4] tested in a cluster RCT, whether receiving care from a specialized health visitor is effective in preventing depression in low-risk women. 2241 adult pregnant women at low risk (EPDS score < 12) received either psychologically orientated sessions based on cognitive behavioral therapy (CBT) or person-centered principles for 8 weeks or usual postpartum care. Primary outcome was depressive symptoms. At 6 months postpartum more women in the control group scored $\geqslant 12$ on the EPDS than in the intervention group $(p=0.016)$. The covariates living alone, having a history of postnatal depression, having experienced an adverse life event and the 6-week EPDS score were significant predictors of PPD at 6 months $(p=0.031)$.

Mao et al. [7] studied the impact of an emotional self-management training program on postnatal depression symptomology. 240 primiparous pregnant females enrolled in the RCT. The emotional self-management group training program, which is based on CBT with elements of Chinese culture of delivery included 4 weekly group sessions and 1 individual counseling session, whereas the control group received usual antenatal care (four 90 -minute childbirth education sessions). Primary outcome was depressive symptoms. Results show significantly lower mean score of PHQ-9 at 36 weeks antenatal in the intervention group compared to the control group $(\mathrm{p}<0.01)$ and significantly lower mean score of EPDS at 6 weeks postnatal in the intervention group than in the control group $(p<0.05)$. This resulted in more people having PPD within the control group $(p<0.05)$.

In Kozinszky et al.'s [32] study the impact of a preventive group intervention for PPD was investigated. All pregnant women living in the catchment area were approached for the RCT, resulting in 1719 participants. Psychoeducation and psychotherapy for PPD were held in group sessions, including elements of interpersonal psychotherapy (IPT) and CBT. The control group received treatment as usual but in group meetings, also 4 times. Primary outcome was depressive symptoms. There were significant lower LQ scores $(p<0.001)$ and PPD prevalences $(p<0.01) 6$ weeks postpartum in the intervention group than the control group.

Moshki et al. [26] assessed the effectiveness of application of health locus of control (HLC) for prevention of PPD. In a pre-post experimental design with a control group, 230 pregnant females with 28-30 weeks gestation took part. The intervention combined information on anatomical and physiological changes, nutrition, common complications during pregnancy, mental health and communication skills, familiarity with stages of pregnancy, delivery and pain reduction methods, postpartum health, emotions and attitudes of women. This was performed with particular emphasis on components of the HLC, including internal HLC, strong other HLC and random HLC, lasting in total 36 hours. The control group received usual postpartum care. Primary outcomes were health behaviors according to participants' beliefs and depressive symptoms. This led to a significantly reduced chance HLC ( $p=0.003)$ and a significantly increased internal HLC $(p=0.03)$ immediately after the intervention. Moreover, a significant difference between the two groups in reduced PPD outcomes one month after intervention $(p=0.001)$ and a significant correlation between internal belief $(p<0.05)$ and chance belief $(p<0.01)$ with EPDS was found.

Hiscock et al. [6] evaluated in a RCT a program for preventing infant sleep and cry problems and postnatal depression. 781 infants born at 32 weeks or later were recruited with their families to participate. The intervention supplied various informations on topics like infant sleep, cry behavior and settling techniques. Families in the control group received usual childcare. Primary outcome was depressive symptoms and sleep quality and quantity. Between the two caregiver groups there were no differences in depression symptoms at 4 months $(p=0.07)$, but a significant greater reduction of depressive symptoms in the intervention caregivers at 6 months $(p=0.03)$ was found.

Nugent et al. [27] tested the efficacy of the Newborn Behavioral Observations (NBO) in lowering postnatal depression. 104 primiparous mothers were eligible for the participation in this RCT. The inclusion criteria were raising the baby with the baby's father, having a vaginal delivery between 36 and 42 weeks of gestation and an Apgar score above 7. The intervention included routine care plus NBO within two days post-delivery (in hospital) and one-month postpartum 
(during home visit), meaning 18 NBO of behavioral spectrum of infants along four dimensions (autonomic, motor, state organization and attentionalinteractional). The control group received, next to the usual postpartum care, a short home visit to carry out the EPDS. Primary outcome was depressive symptoms. The intervention group had significantly fewer mothers with elevated depression scores compared to the control group ( $p=0.05)$.

Maimburg et al. [36] studied the influence of a structured general antenatal program on PPD. 1062 nulliparous adult pregnant females between $10+0$ to $21+$ 6 days of gestation with a singleton pregnancy took part in the parallel RCT. The antenatal education program was conducted between the 30th - 35th weeks of gestation. It provided material on the content of the birth module, the newborn module and the parent module with information about PPD, lasting 9 hours in total. The control group received usual antenatal care. Primary outcome were depressive symptoms and identifying risk factors for PPD. There were no significant differences in EPDS scores at 6 weeks postpartum between the two groups (OR=0.89, 95\% $\mathrm{Cl}: 0.57-1.40)$.

Dimidjian et al. [30] evaluated treatment acceptability and efficacy of mindfulness-based cognitive therapy adapted for perinatal depression (MBCT-PD). 86 adult pregnant females with $>32$ weeks gestation that met criteria for prior major depressive disorder (but not in the last two months) participated in the pilot randomized clinical trial. The MBCT-PD consisted of eight sessions and additionally at-home practice for 6 days each week between Sessions 1 and 7 . The intervention lasted 42 days in total. They were compared to the control group, which received usual antenatal care. Primary outcomes were baseline diagnostic status, treatment acceptability, women's satisfaction with study condition, depression relapse/recurrence and depression symptom severity. The intervention group had significantly improved depressive outcomes compared to the control group, including significantly lower rates of depressive relapse/recurrence $(p=0.005)$ in the postpartum period and fewer depressive symptoms throughout the trial $(p=0.002)$.

Werner et al. [41] examined the effectiveness of Practical Resources for Effective Postpartum Parenting (PREPP) to treat women at risk for PPD. In a RCT 54 pregnant females in 2nd or 3rd trimester of their pregnancy and at high-risk (score of $>24$ on Predictive Index of Postnatal Depression), aged 18-45 years took part. The intervention included 3 PREPP sessions in which five specific infant behavioral (feeding, day-night rhythm, carrying duration, swaddling) and mindfulness techniques were covered. Moreover, the participants received supportive psychological interviewing (using motivational interviewing techniques) and psychoeducation conducted by a psychologist. Participants in the control group received enhanced treatment as usual, they met on two occasions with a psychologist and were provided with information about PPD and referred to treatment if necessary. Primary outcome were depressive symptoms, symptoms of anxiety and infant fuss/cry episodes. This showed significantly decreased depressive symptoms in the intervention group in contrast to the control group $(p=0.01)$ at $36-38$ weeks gestation and 6 weeks postpartum and significantly more depressive symptoms at 6 weeks postpartum in control group in contrast to intervention group $(p=0.02)$.

Tsai et al. [25] evaluated the link between food shortages, depression and the role of social support. For this population-based, cluster-randomized trial all pregnant females living in the study catchment area who were willing to participate were recruited, resulting in 958 subjects. The home visiting intervention offered problem-solving and cognitive-behavioral techniques on topics like HIV, tuberculosis, malnutrition and alcohol use in 4 visits and a 36-month follow-up interview. The control group received standard clinic care which consisted of primary health care, tuberculosis and HIV testing, antiretroviral therapy, antenatal and postnatal care. Primary outcomes were depression symptom severity, number of days of hunger in the past week and emotional and instrumental support. This trial showed a strong significant association between lagged food insufficiency and depression symptom severity ( $\beta=0.70 ; 95 \% \mathrm{Cl}, 0.46-0.94)$, no statistically significant association with food insufficiency and depression symptom severity among women with a level of instrumental support greater than the median ( $\beta=0.12 ; 95 \% \mathrm{Cl},-0.35$ to 0.59$)$, but a significant association between food insufficiency and depression among women with low levels of instrumental support $(\beta=0.79 ; 95 \% \mathrm{Cl}, 0.51-1.07)$.

Duncan et al. [31] conducted a mindfulness-based childbirth preparation course. In the RCT 29 primiparous pregnant females in the last part of their singleton pregnancy with no extensive prior experience with meditation or yoga practice were suitable. The intervention group participated in the program called Mind in Labor (MIL): Working with Pain in Childbirth [31], which is a 2.5-day mindfulness-based childbirth preparation course based on Mindfulness-Based Childbirth and Parenting (MBCP). The control group received usual antenatal care and a list of approved, comparable childbirth courses, but with no mind-body focus. Primary outcomes were childbirth self-efficacy, maladaptive pain appraisal, perceived pain in labor, use of pain medication in labor, using medical record review, birth satisfaction and depression. Results for perinatal and PPD symptoms showed a significant interaction between group and time ( $\mathrm{p}=0.04)$, the estimated treatment effect was $-3.34(80 \% \mathrm{Cl}[-5.22,-1.28])$.

\section{Psychosocial interventions}

Barnes et al. [28] evaluated in a cluster-randomized study if a home-visiting support program is effective in preventing maternal depression. 250 adult mothers with social disadvantage (Social Disadvantage Screening Index score >9), infant birthweight $\geq 2500 \mathrm{~g}$ and infant being under 5 days in special care baby unit took part. The home visits included different activities like providing advice or assistance with childcare and varied individually in length and frequency. The matched control group receiving no support and those who declined home-start-support also receiving no support were compared to the intervention group. Primary outcomes were major or minor depression and depressive symptoms. Depression at 2 months was the only significant predictor for having depression at 12 months. Social support at 2 months led to significantly lower depression scores $(p<0.0001)$.

In a cross-sectional RCT, Dennis [29] evaluated whether peer support is effective in the prevention of PPD. 701 adult mothers with a EPDS baseline score < 9 participated. In contrast to the control group, which just received usual postpartum care, the intervention group also received telephone-based peer support, which provided emotional, informational and appraisal support. Primary outcome was maternal perceptions of peer support, which was evaluated by using PSEl at 12 weeks postpartum. The items in Maternal perceptions of perceived benefits subscale the perspective Stress and Coping in the domain Depression showed moderate to strong correlations (Life is more enjoyable $(r=0.41)$, Less depressed $(r=0.62)$ [29]), resulting in significantly lower EPDS scores at 12 weeks in the intervention group $(\mathrm{p}<0.001)$. 
Dugravier et al. [5] tested in a prospective RCT the impact of a home-visiting program conducted by psychologists on postnatal depression. 367 primiparous pregnant females with 12-27 weeks gestation who are under 26 years old and fulfill at least one of the following characteristics: "1) having less than twelve years of education, 2) planning to bring up their child without the child's father, 3) having low income" [5] took part. The CAPEDP (Compétences parentales et Attachement dans la Petite Enfance: Diminution des risques lies aux troubles de santé mentale et Promotion de la résilience- Parental Skills and Attachment in Early Childhood: reducing mental health risks and promoting resilience [5]) included 14 intensive multifocal home visits done by psychologists who promoted mental and physical health and provided support. It lasted for 12 months, with a 27-month follow-up. The control group received usual postpartum care. Primary outcome was depressive symptoms. The home-visiting program had no overall impact on postnatal depression symptomatology, however posthoc analysis revealed that the intervention group had significantly lower EPDS scores in the following subgroups: women with lower depressive scores at inclusion $(p=0.05)$, women who were planning on cohabiting with the child's father $(p=0.04)$ and well-educated women $(p=0.05)$.

Lewis et al. [35] examined the relation between employment status and PPD among high-risk women. This was a post hoc analysis from a previously conducted RCT, which was also included in this review and is described in more detail below (see [34]). 124 healthy women (six participants were lost to follow-up), who had a (maternal family) history of depression aged between 18-42 years have been examined. They filled out a demographic questionnaire, completed a telephone interview at the beginning of the study on race/ethnicity, age, body mass index and use of antidepressants, and a telephone interview after 7 months on employment and breastfeeding status and history of depression. Lewis et al. found evidence for a significant association between employment status and higher depression symptomatology $(p=0.010)$, especially employed women at 7 months postpartum had significantly fewer depressive symptoms than non-employed women. However, there were no significant differences between women who worked full-time versus part-time on depression symptoms $(r=-0.022$, ns.). They also found a significant correlation between being single and higher depression symptomatology at 7 months postpartum $(\mathrm{p}=0.001)$.

\section{Nutritional interventions}

Mozurkewich et al. [37] conducted a double-blind RCT to investigate whether different types of fish oil supplementation lowers depressive symptoms during pregnancy or postpartum. 126 adult pregnant women with 12-20 weeks gestation and at risk for PPD took part. They either received 6 capsules of EPA-rich (1060 mg EPA plus $274 \mathrm{mg} \mathrm{DHA}$ ) fish oil supplementation or DHA-rich ( $900 \mathrm{mg}$ DHA plus $180 \mathrm{mg}$ EPA) fish oil supplements or soy oil placebo twice daily for 3 months. No differences between the groups in any depression outcomes at any of the three time points after supplementation were found (significance=0.051). but DHA levels did predict BDI score at 34-36 weeks $(p<0.05)$.

Vaz et al. [38] evaluated the efficacy of fish oil supplementation on the prevention of PPD. 32 pregnant females who were at risk for PPD (past history of depression or baseline EPDS score $\geq 9$ ), between 5-13 weeks of gestation at the time of enrolment and aged 20-40 years were eligible to participate in the randomized, placebo-controlled, double blind trial. They either received 6 capsules per day of fish oil (1.08 $\mathrm{g}$ of EPA and $0.72 \mathrm{~g}$ of DHA) or soybean oil placebo starting at week 22-24 of gestation for 16 consecutive weeks. Primary outcomes were prevalence of EPDS, length of gestation and birth weight. There were no significant differences between intervention and control groups in EPDS scores (T0 p=0.809, T1 p=0.299, T2 p=0.630, T3 p=1.000), but women in the intervention group with a history of depression scored significantly lower on the EPDS from the second to the third trimester in the ITT analyses compared to the control group $(p=0.038)$.

Young et al. [40] analyzed the maternal placentophagy's effect on postpartum mood, energy, and bonding. 27 adult pregnant females who had previously decided they would ingest their placenta after birth took part in the randomized, double-blind, placebo-controlled pilot study. Participants consumed their processed, encapsulated placenta: two $550 \mathrm{mg}$ capsules 3 times daily for the first 4 days of supplementation, decreased the dosage of 2 capsules twice daily on days 5 through 12 of supplementation, and reduced the dosage to 2 capsules once daily through completion. The control group received a similarly prepared placebo with the same intake times. Both groups had 4 meetings with researchers. Primary outcomes were basic demographic information, various psychometric, social and lifestyle variables, depression symptoms, salvia sample, length and weight of the neonate. No significant main effects were found $(p=0.016)$.

\section{Medical interventions}

Xu et al.[39] evaluated in a randomized, double-blind, placebo-controlled design the preventive effect of ketamine on PPD. 330 women who were scheduled to undergo caesarean section with spinal anesthesia received either intravenous low-dose ketamine $(0.25 \mathrm{mg} / \mathrm{kg}$ diluted to $10 \mathrm{~mL}$ with $0.9 \%$ saline $)$ or placebo ( $10 \mathrm{~mL}$ of $0.9 \%$ saline) within a short time after giving birth. Primary outcome was depression. There were no significant differences found between the two groups in the prevalence of PPD at 3 days $(p=0.965)$ and 6 weeks $(p=0.900)$ after delivery.

\section{Exercise}

Lewis et al. [34] examined in a RCT the effectiveness of a telephone-based exercise program in preventing PPD among high-risk women. 130 adult mothers with a (maternal family) history of depression who are currently not exercising were recruited for The Healthy Mom Study. The intervention group took part in a telephone-based exercise intervention including telephone counseling sessions, motivational print materials and completion of exercise logs. The wellness/support contact control condition provided a counselor who only gave support for general issues related to health and wellness and no information regarding exercise, also lasting 6 months. Primary outcome was depression. There were no significant differences in PHQ-9 ( $p=0.09$ ), PSS ( $p=0.87$ ), and PSQI $(p=0.995)$ scores between participants in the two groups. The three baseline measures were all correlated with one another: PHQ-9 scores were significantly correlated with the PSS scores $(r=0.43, p<0.0001)$ and PSQI scores $(r=0.41, p<0.0001)$.

Songøygard et al. [8] investigated whether exercising during pregnancy is effective in preventing postnatal depression. They conducted a RCT with 719 adult pregnant women. The intervention consisted of a 12-week exercise program exercise groups once weekly and a 45-min home exercise program several times a 
week, starting from week 20 of pregnancy. The control group received usual antenatal care. Primary outcome was depressive symptoms. There were no significant differences in depressive symptoms between the two groups $(p=0.35)$, but women in the intervention group who did not engage in physical activity regularly before pregnancy had a reduced risk of postnatal depression $(p<0.05)$.

\section{Discussion}

PPD is one of the most frequent mental diseases of the perinatal period [1] and the importance of prevention of PPD has been highlighted frequently [11, 19, 21]. Therefore, the aim of this current review was to provide an overview of current literature on preventive interventions for PPD in adult mothers. In our systematic review we have investigated 22 studies in total. Out of these, 12 studies included psychological interventions, four studies included psychosocial interventions, three studies included nutritional interventions, one study performed a medical intervention and two studies included exercise programs. 15 studies had a significant effect in preventing PPD. All psychological interventions investigated showed a significant preventive effect concerning PPD, except for one [36]. The psychological interventions which included psychoeducation, elements of CBT and IPT, prevention programs, home visits and a focus on mindfulness had a significant impact in the reduction of PPD. The study of Maimburg et al. [36] carried out an antenatal education program with information about birth and PPD. In comparison to the other studies investigated the intervention was carried out relatively late in pregnancy (30-35 weeks of gestation), which may be a possible explanation for lack of significant preventive effect.

All psychosocial interventions showed significant effects, they contained home-visiting and peer support. Nutritional interventions did not show any significant effects. In the studies of Mozurkewich et al. [37] and Vaz et al. [38] Omega 3 supplementation was given to pregnant women. Both studies did not show significant results regarding the prevention of PPD, which leads to the assumption that Omega 3 is not effective in that case. Young et al. [40] investigated the effects of placentophagy. No significant results were found, this might be due to the small sample size $(\mathrm{n}=27)$. The medical intervention showed no significant effect, this could be caused by the fact that in the study of Xu et al. [39] a relatively low dose of ketamine ( $0.25 \mathrm{mg} / \mathrm{kg}) \mathrm{was}$ used. Exercise programs did not result in an overall lower prevalence of PPD, but only partially in one study [8]. One difference was, that Lewis et al. [34] examined women postpartum (on average 5.7 weeks postpartum), whereas the intervention of Songøygard et al. [8] took place during pregnancy. Songøygard et al. found that a subgroup of women in the intervention group who did not exercise regularly prior to pregnancy but then exercised during pregnancy had a reduced risk of PPD, indicating that exercise programs during pregnancy can be effective among certain participants for preventing PPD.

These results can be compared with the findings of previous reviews. Sangsawang et al. [21] found effective results for psychological and psychosocial interventions, whereas Werner et al. [19] found both significant and non-significant effects for psychological and psychosocial interventions. In line with those findings, we found psychological and psychosocial interventions to be effective in the prevention of PPD. Werner et al. showed that biological interventions, namely with anti-depressants and nutrients provided the most evidence, but interventions using thyroxine, Omega 3 and progestogen showed negative results. In our study no comparable intervention was successful. A factor that could be responsible for this is that these groups had the lowest total number of participants (nutritional $n=185$, medical $n=330$ ). Parallels can be drawn for Omega 3 , since both studies in our review investigating the effect of Omega 3 on PPD in high risk women led to negative results, as well as the three negative results of Werner et al. investigating Omega 3 effect's on low risk women led to the assumption that Omega 3 is not effective in lowering PPD symptoms. In summary, significant effects were found for home visits, psychoeducation, preventative measures, CBT and IPT in both the review of Sangsawang et al. and ours. Nevertheless, their work focused on American adolescent mothers up to the age of 19 years and therefore cannot be generalized to mothers of all ages and ethnicities and should be interpreted with that in mind. There is accordance regarding the review by Werner et al. and our results in the following interventions: IPT, CBT and preventative measures.

The majority of the studies did not put any emphasis on reaching over or under certain cut-offs for baseline depression scores, nor was there a special focus on ethnic minority populations. Due to the fact, that the studies were conducted globally, a wide variability of various populations in different cultures and countries was ensured. The findings may be generalized and implemented in the general adult female population of childbearing age.

Most of the studies ( $n=19)$ classified as strong quality, none had poor quality. The items 5 (random allocation), 6 and 7 (blinding of investigator and subjects) and 9 (appropriate sample size) were the ones where reporting was most lacking. Therefore, more attention should be drawn to proper randomization techniques including the description of the method used, if applicable reporting of blinding of investigators and subjects, if not, clearly saying why not applicable and having a large enough sample size based on sample size calculations and mentioning of power/effect size.

It is important to foster the research regarding the topic of preventive interventions for PPD since there are ambivalent findings. Implications for future research might include the comparison of already existing prevention programs for PPD and the observation of their long-term effects.

\section{Limitations}

Our study has several limitations. The search term was strictly limited to a combination of postpartum or postnatal depression, predictor, prevention and risk factor. This excludes some studies that may be important for this work in advance. For example, studies that focus on the Baby Blues were neglected, which might be interesting since there is a link between Baby Blues and PPD [10]. Furthermore, only three databases were used to conduct the electronic search, meaning there was no greater variability in the outcome sources. Another limitation is that the screening of PPD symptoms varied widely between the different studies. Although at the beginning we determined the primary outcomes with depressive symptoms and major or minor depression with peripartum onset, it would have been more consistently and comparable if we had decided on a reliable screening instrument, like the EPDS, to measure PPD [42].

\section{Conclusions}

15 studies had a significant effect in preventing PPD. Of these 15 studies, 11 psychological interventions and four psychosocial interventions showed significant effects of lower depression scores. To conclude this systematic review, effective interventions should include the following: psychoeducation, 
elements of CBT and IPT, preventatives measures, home visits, peer support, and a focus on mindfulness.

\section{Abbreviations}

BDI-II=Beck Depression Inventory

CAPEDP=Promoting Parental Skills and Enhancing Attachment in Early Childhood

$\mathrm{CBT}=$ Cognitive behavioral therapy

CES-D $=$ Center for Epidemiologic Studies-Depression Scale

CORE-OM=Clinical Outcomes in Routine Evaluation - Outcome Measure

DASS-21=Depression Anxiety Stress Scales

DHA=Docosapentaenoic

$\mathrm{ESMGT}=$ Emotional self-management group training

$\mathrm{EPA}=$ Eicosapentaenoic

EPDS=Edinburgh Postnatal Depression Scale

EPS=Edinburgh Postnatal Scale

FAS=Fatigue Assessment Scale

HFIAS=Household Food Insecurity Access Scale

HLC=Health locus of control

HRSD=Hamilton Rating Scale for Depression

ICQ=Infant Characteristics Questionnaire

ITT=Intention-to-treat

$\mathrm{KBQ}=$ Kennerley Blues Questionnaire

LIFE=Longitudinal Interval Follow-up Evaluation

LQ=Leverton Questionnaire

MBCP=Mindfulness-Based Childbirth and Parenting

MBCT-PD=Mindfulness-based cognitive therapy for perinatal depression

MHLCS=Multidimensional Health Locus of Control Scale

MIBS=Mother-to-Infant Bonding Scale

MIL=Mind in Labor: Working with Pain in Childbirth

MINI=Mini International Neuropsychiatric Interview

MSSI=Maternal Social Support Index

NBO=Newborn Behavioral Observations

PPD $=$ Postpartum depression

PHQ-9=Patient Health Questionnaire

PREPP $=$ Practical Resources for Effective Postpartum Parenting

PSEI=Peer Support Evaluation Inventory

PSI=Parenting Stress Index

PSI-SF = Parenting Stress Index Short Form 
PSQI=Pittsburgh Sleep Quality Index

PSS=Perceived Stress Scale

$\mathrm{RCT}=$ Randomized controlled trial

$S C I D=S t r u c t u r e d$ Clinical Interview for Diagnostic and Statistical Manual

SCID-I/P=Structured Clinical Interview for DSM-IV-TR Axis I Disorders

SCID-II=Structured Clinical Interview for DSM-IV Axis II Personality Disorders

SCL-90-R=Symptom Checklist-90-Revised

SF-12=12-item Short Form Health Survey

STAI=State- Trait Anxiety Inventory

\section{Declarations}

\section{Ethics approval and consent to participate}

Not applicable.

\section{Consent for publication}

Not applicable.

\section{Availability of data and materials}

All data generated or analyzed during this study are included in this published article and its supplementary information files.

\section{Competing interests}

The authors declare that they have no competing interests.

\section{Funding}

Not applicable.

\section{Authors' contributions}

NM undertook the literature search and analysis and wrote the first draft of the manuscript. KF contributed to the analysis and writing of the manuscript and took the lead in redrafting. TO reviewed the manuscript. All of the authors read and approved the final manuscript.

\section{Acknowledgements}

This research paper submitted in partial fulfillment of the requirements for the degree Bachelor of Science in the degree program Psychology and Psychotherapy at the University Witten/Herdecke.

\section{References}

1. Sit DK, Wisner KL. The Identification of Postpartum Depression. Clin Obstet Gynecol. 2009;52:456-68.

2. American Psychiatric Association. Diagnostic and Statistical Manual of Mental Disorders. 5th edition. Arlington, VA: American Psychiatric Publ.; 2013.

3. Fehr S. Postnatale Depression - PostNATAL oder postPARTAL? 2016. https://www.postnatale-depression.ch/de/informationen/news/item/postnatal-oderpostpartal.html. Accessed 10 Mar 2020.

4. Brugha TS, Morrell CJ, Slade P, Walters SJ. Universal prevention of depression in women postnatally: cluster randomized trial evidence in primary care. Psychol Med. 2011;41:739-48.

5. Dugravier R, Tubach F, Saias T, Guedeney N, Pasquet B, Purper-Ouakil D, et al. Impact of a Manualized Multifocal Perinatal Home-Visiting Program Using Psychologists on Postnatal Depression: The CAPEDP Randomized Controlled Trial. PLoS One. 2013;8. doi:10.1371/journal.pone.0072216.

6. Hiscock H, Cook F, Bayer J, Le H, Mensah F, Cann W, et al. Preventing Early Infant Sleep and Crying Problems and Postnatal Depression: A Randomized Trial. Pediatrics. 2014;133.

7. Mao H-J, Li H-J, Chiu H, Chan W-C, Chen S-L. Effectiveness of antenatal emotional self-management training program in prevention of postnatal depression in Chinese women. Perspect Psychiatr Care. 2012;48:218-24.

8. Songøygard KM, Stafne SN, Evensen KAl, Salvesen KÅ, Vik T, Mørkved S. Does exercise during pregnancy prevent postnatal depression? A randomized controlled trial. Acta Obstet Gynecol Scand. 2012;91:62-7. 
9. Lanczik M, Brockington IF. Das postpartale dysphorische Syndrom. Fortschr Neurol Psychiatr. 1999;67:60-7.

10. Dorsch VM, Rohde A. Postpartale psychische Störungen - Update 2016. Frauenheilkunde up2date. 2016;10:355-74.

11. O'Hara MW, McCabe JE. Postpartum depression: current status and future directions. Annu Rev Clin Psychol. 2013;9:379-407.

12. v Ballestrem C-L, Strauss M, Kächele H. Contribution to the epidemiology of postnatal depression in Germany-implications for the utilization of treatment. Arch Womens Ment Health. 2005;8:29-35.

13. Halbreich U, Karkun S. Cross-cultural and social diversity of prevalence of postpartum depression and depressive symptoms. J Affect Disord. 2006;91:97-111.

14. Ertop F, Cetisli N. Postpartum depression and breastfeeding in overweight / obese and non-obese mothers. J Pak Med Assoc. 2019 ;:1.

15. Stillen. 2020. https://www.mri.bund.de/de/themen/nationale-stillkommission/nationale-stillkommission/stillen/. Accessed 26 Apr 2019.

16. Vaever MS, Pedersen IE, Smith-Nielsen J, Tharner A. Maternal postpartum depression is a risk factor for infant emotional variability at 4 months. Infant Ment Health J. 2020.

17. Gotlib IH, Whiffen VE, Mount JH, Milne K, Cordy NI. Prevalence rates and demographic characteristics associated with depression in pregnancy and the postpartum. J Consult Clin Psychol. 1989;57:269-74.

18. Guintivano J, Manuck T, Meltzer-Brody S. Predictors of Postpartum Depression: A comprehensive review of the last decade of evidence. Clin Obstet Gynecol. 2018;61:591-603.

19. Werner, Miller M, Osborne LM, Kuzava S, Monk C. Preventing postpartum depression: Review and recommendations. Arch Womens Ment Health. 2015;18:41-60.

20. Šebela A, Hanka J, Mohr P. Etiology, risk factors, and methods of postpartum depression prevention. Ceska Gynekol. 2018;83:468-73.

21. Sangsawang B, Wacharasin C, Sangsawang N. Interventions for the prevention of postpartum depression in adolescent mothers: a systematic review. Arch Womens Ment Health. 2019;22:215-28.

22. Moher D, Liberati A, Tetzlaff J, Altman DG. Preferred reporting items for systematic reviews and meta-analyses: the PRISMA statement. BMJ. $2009 ; 339$. doi:10.1136/bmj.b2535.

23. Kmet LM, Lee RC, Cook LS, Alberta Heritage Foundation for Medical Research, University of Calgary, Faculty of Medicine, et al. Standard quality assessment criteria for evaluating primary research papers from a variety of fields. Edmondton, Alta.: Alberta Heritage Foundation for Medical Research; 2004.

24. O'Connor D, Green S, Higgins JP. Defining the Review Question and Developing Criteria for Including Studies. In: Cochrane Handbook for Systematic Reviews of Interventions. John Wiley \& Sons, Ltd; 2008. p. 81-94. doi:10.1002/9780470712184.ch5.

25. Tsai AC, Tomlinson M, Comulada WS, Rotheram-Borus MJ. Food Insufficiency, Depression, and the Modifying Role of Social Support: Evidence from a Population-Based, Prospective Cohort of Pregnant Women in Peri-Urban South Africa. Soc Sci Med. 2016;151:69-77.

26. Moshki M, Beydokhti TB, Cheravi K. The effect of educational intervention on prevention of postpartum depression: an application of health locus of control. Journal of Clinical Nursing. 2014;23:2256-63.

27. Nugent JK, Bartlett JD, Valim C. Effects of an Infant-Focused Relationship-Based Hospital and Home Visiting Intervention on Reducing Symptoms of Postpartum Maternal Depression: A Pilot Study. Infants \& Young Children. 2014;27:292-304.

28. Barnes J, Senior R, MacPherson K. The utility of volunteer home-visiting support to prevent maternal depression in the first year of life. Child: Care, Health and Development. 2009;35:807-16.

29. Dennis C-L. Postpartum depression peer support: Maternal perceptions from a randomized controlled trial. International Journal of Nursing Studies. 2010;47:560-8.

30. Dimidjian S, Goodman SH, Felder J, Gallop R, Brown AP, Beck A. Staying Well during Pregnancy and the Postpartum: A Pilot Randomized Trial of Mindfulness Based Cognitive Therapy for the Prevention of Depressive Relapse/Recurrence. J Consult Clin Psychol. 2016;84:134-45.

31. Duncan LG, Cohn MA, Chao MT, Cook JG, Riccobono J, Bardacke N. Benefits of preparing for childbirth with mindfulness training: a randomized controlled trial with active comparison. BMC Pregnancy Childbirth. 2017;17. doi:10.1186/s12884-017-1319-3.

32. Kozinszky Z, Dudas RB, Devosa I, Csatordai S, Tóth É, Szabó D, et al. Can a Brief Antepartum Preventive Group Intervention Help Reduce Postpartum Depressive Symptomatology? PPS. 2012;81:98-107.

33. Lara MaA, Navarro C, Navarrete L. Outcome results of a psycho-educational intervention in pregnancy to prevent PPD: A randomized control trial. Journal of Affective Disorders. 2010;122:109-17.

34. Lewis BA, Gjerdingen DK, Avery MD, Guo H, Sirard JR, Bonikowske AR, et al. Examination of a Telephone-Based Exercise Intervention for the Prevention of Postpartum Depression: Design, Methodology, and Baseline Data from The Healthy Mom Study. Contemp Clin Trials. 2012;33:1150-8.

35. Lewis BA, Billing L, Schuver K, Gjerdingen D, Avery M, Marcus BH. The relationship between employment status and depression symptomatology among women at risk for postpartum depression. Womens Health (Lond). 2017;13:3-9.

36. Maimburg RD, Vaeth M. Postpartum depression among first-time mothers - results from a parallel randomised trial. Sex Reprod Healthc. 2015;6:95-100.

37. Mozurkewich EL, Clinton CM, Chilimigras JL, Hamilton SE, Allbaugh LJ, Berman DR, et al. The Mothers, Omega-3, and Mental Health Study: a doubleblind, randomized controlled trial. Am J Obstet Gynecol. 2013;208:313.e1-313.e9.

38. Vaz J dos S, Farias DR, Adegboye ARA, Nardi AE, Kac G. Omega-3 supplementation from pregnancy to postpartum to prevent depressive symptoms: a randomized placebo-controlled trial. BMC Pregnancy Childbirth. 2017;17. doi:10.1186/s12884-017-1365-x. 
39. Xu Y, Li Y, Huang X, Chen D, She B, Ma D. Single bolus low-dose of ketamine does not prevent postpartum depression: a randomized, double-blind, placebo-controlled, prospective clinical trial. Arch Gynecol Obstet. 2017;295:1167-74.

40. Young SM, Gryder LK, Cross C, Zava D, Kimball DW, Benyshek DC. Placentophagy's effects on mood, bonding, and fatigue: A pilot trial, part 2. Women Birth. 2018;31:e258-71.

41. Werner, Gustafsson HC (co-first), Lee S, Feng T, Jiang N, Desai P, et al. PREPP: Postpartum Depression Prevention through the Mother-Infant Dyad. Arch Womens Ment Health. 2016;19:229-42.

42. Smith-Nielsen J, Matthey S, Lange T, Væver MS. Validation of the Edinburgh Postnatal Depression Scale against both DSM-5 and ICD-10 diagnostic criteria for depression. BMC Psychiatry. 2018;18:393.

\section{Tables}

\section{Table 1}




\begin{tabular}{|c|c|c|c|c|c|c|c|c|c|}
\hline \multicolumn{10}{|l|}{ Items } \\
\hline Authors & $\begin{array}{l}1 . \\
\text { Question / } \\
\text { objective } \\
\text { sufficiently } \\
\text { described? }\end{array}$ & $\begin{array}{l}\text { 2. Study } \\
\text { design } \\
\text { evident and } \\
\text { appropriate? }\end{array}$ & $\begin{array}{l}\text { 3. Method of } \\
\text { subject/comparison } \\
\text { group selection or } \\
\text { source of } \\
\text { information/input } \\
\text { variables described } \\
\text { and appropriate? }\end{array}$ & $\begin{array}{l}\text { 4. Subject } \\
\text { (and } \\
\text { comparison } \\
\text { group, if } \\
\text { applicable) } \\
\text { characteristics } \\
\text { sufficiently } \\
\text { described? }\end{array}$ & $\begin{array}{l}5 . \\
\text { Random } \\
\text { allocation }\end{array}$ & $\begin{array}{l}\text { 6. Blinding } \\
\text { of } \\
\text { investigators }\end{array}$ & $\begin{array}{l}7 . \\
\text { Blinding } \\
\text { of } \\
\text { subjects }\end{array}$ & $\begin{array}{l}\text { 8. Outcome } \\
\text { and (if } \\
\text { applicable) } \\
\text { exposure } \\
\text { measure(s) } \\
\text { well defined } \\
\text { and robust to } \\
\text { measurement }\end{array}$ & $\begin{array}{l}\text { 9. Sampl } \\
\text { size } \\
\text { approprii }\end{array}$ \\
\hline $\begin{array}{l}\text { Barnes et al. } \\
2009\end{array}$ & 2 & 2 & 2 & 2 & 2 & 2 & 2 & 2 & 1 \\
\hline $\begin{array}{l}\text { Dennis CL. } \\
2010\end{array}$ & 2 & 2 & 2 & 2 & 1 & 2 & 0 & 2 & 1 \\
\hline $\begin{array}{l}\text { Lara et al. } \\
2010\end{array}$ & 2 & 2 & 2 & 2 & 2 & 0 & 0 & 2 & 1 \\
\hline $\begin{array}{l}\text { Brugha et al. } \\
2011\end{array}$ & 2 & 2 & 2 & 2 & 2 & 2 & 0 & 2 & 2 \\
\hline $\begin{array}{l}\text { Lewis et al. } \\
2012\end{array}$ & 2 & 2 & 2 & 2 & 2 & 2 & 0 & 2 & 2 \\
\hline $\begin{array}{l}\text { Mao et al. } \\
2012\end{array}$ & 2 & 2 & 2 & 2 & 2 & 2 & 0 & 2 & 1 \\
\hline $\begin{array}{l}\text { Songøygard } \\
\text { et al. } 2012\end{array}$ & 2 & 2 & 2 & 2 & 2 & $\mathrm{n} / \mathrm{a}$ & $\mathrm{n} / \mathrm{a}$ & 2 & 2 \\
\hline $\begin{array}{l}\text { Kozinszky et } \\
\text { al. } 2012\end{array}$ & 2 & 2 & 1 & 2 & 2 & 2 & 2 & 2 & 1 \\
\hline $\begin{array}{l}\text { Mozurkewich } \\
\text { et al. } 2013\end{array}$ & 2 & 2 & 2 & 2 & 2 & 2 & 2 & 2 & 2 \\
\hline $\begin{array}{l}\text { Dugravier et } \\
\text { al. } 2013\end{array}$ & 2 & 2 & 2 & 2 & 2 & 2 & 2 & 2 & 2 \\
\hline $\begin{array}{l}\text { Moshki et al. } \\
2014\end{array}$ & 2 & 2 & 2 & 2 & 1 & 0 & 0 & 2 & 1 \\
\hline $\begin{array}{l}\text { Hiscock et al. } \\
2014\end{array}$ & 2 & 2 & 2 & 2 & 2 & $\mathrm{n} / \mathrm{a}$ & $\mathrm{n} / \mathrm{a}$ & 2 & 2 \\
\hline $\begin{array}{l}\text { Nugent et al. } \\
2014\end{array}$ & 2 & 2 & 1 & 2 & 2 & 0 & 0 & 2 & 2 \\
\hline $\begin{array}{l}\text { Maimburg et } \\
\text { al. } 2015\end{array}$ & 2 & 2 & 2 & 2 & 2 & 2 & 0 & 2 & 2 \\
\hline $\begin{array}{l}\text { Dimidjian et } \\
\text { al. } 2016\end{array}$ & 2 & 2 & 2 & 2 & 1 & 2 & 0 & 2 & 1 \\
\hline $\begin{array}{l}\text { Werner et al. } \\
2016\end{array}$ & 2 & 2 & 2 & 2 & 1 & 2 & 0 & 2 & 1 \\
\hline $\begin{array}{l}\text { Tsai et al. } \\
2016\end{array}$ & 2 & 2 & 1 & 1 & 0 & 0 & 0 & 2 & 1 \\
\hline $\begin{array}{l}\text { Lewis et al. } \\
2017\end{array}$ & 2 & 2 & 2 & 2 & 1 & $\mathrm{n} / \mathrm{a}$ & $\mathrm{n} / \mathrm{a}$ & 2 & 2 \\
\hline $\begin{array}{l}\text { Xu et al. } \\
2017\end{array}$ & 2 & 2 & 2 & 2 & 2 & 2 & 2 & 2 & 2 \\
\hline $\begin{array}{l}\text { Vaz et al. } \\
2017\end{array}$ & 2 & 2 & 2 & 2 & 1 & 2 & 2 & 2 & 2 \\
\hline $\begin{array}{l}\text { Duncan et al. } \\
2017\end{array}$ & 2 & 2 & 2 & 1 & 2 & 2 & 0 & 2 & 1 \\
\hline $\begin{array}{l}\text { Young et al. } \\
2018\end{array}$ & 2 & 2 & 2 & 2 & 1 & 2 & 2 & 2 & 1 \\
\hline
\end{tabular}

Table 2 


\begin{tabular}{|c|c|c|c|c|c|c|c|}
\hline Author(s)/year & Study title & $\begin{array}{l}\text { Study } \\
\text { design }\end{array}$ & $\begin{array}{l}\text { Sample } \\
\text { characteristics }\end{array}$ & Intervention & Control & Outcome & Findings \\
\hline $\begin{array}{l}\text { Barnes et al. } \\
2009\end{array}$ & $\begin{array}{l}\text { The utility of } \\
\text { volunteer home- } \\
\text { visiting support to } \\
\text { prevent maternal } \\
\text { depression in the } \\
\text { first year of life. }\end{array}$ & $\mathrm{RCT}$ & $\begin{array}{l}\text { Adult mothers, } \\
\text { mean age } \\
29.0 \text { years, } \\
\text { infant } \\
\text { birthweight } \\
\geq 2500 \mathrm{~g}, \leq 5 \\
\text { days in } \\
\text { special care } \\
\text { baby unit, } \\
\text { baseline score } \\
\text { on modified } \\
\text { version of SDI } \\
>9,250 \\
\text { subjects }\end{array}$ & $\begin{array}{l}\text { Home-start- } \\
\text { support, included } \\
\text { different } \\
\text { activities like } \\
\text { providing } \\
\text { company, } \\
\text { assistance with } \\
\text { childcare or other } \\
\text { household tasks, } \\
\text { going out on } \\
\text { joint trips to local } \\
\text { facilities or } \\
\text { giving parenting } \\
\text { advice, individual } \\
\text { length and } \\
\text { frequency, } \\
\text { average number } \\
\text { of visits 15.1, } \\
\text { average months } \\
\text { of support were } \\
5.5\end{array}$ & $\begin{array}{l}\text { Matched control } \\
\text { group receiving } \\
\text { no support, those } \\
\text { who declined } \\
\text { home-start- } \\
\text { support also } \\
\text { receiving no } \\
\text { support }\end{array}$ & $\begin{array}{l}\text { Primary outcome: } \\
\text { major or minor } \\
\text { depression } \\
\text { occurring between } \\
2 \text { and } 12 \text { months } \\
\text { by using SCID and } \\
\text { depressive } \\
\text { symptoms at } 12 \\
\text { months by using } \\
\text { EPDS, Secondary } \\
\text { outcome: ICQ, } \\
\text { MSSI, PSI }\end{array}$ & $\begin{array}{l}\text { More social support } \\
\text { at } 2 \text { months } \\
\text { predictor of lower } \\
\text { likelihood of } \\
\text { depression, } \\
\text { Significant predictor } \\
\text { of more depression } \\
\text { symptoms at } 12 \\
\text { months was more at } \\
2 \text { months } \\
(p<0.0001)\end{array}$ \\
\hline $\begin{array}{l}\text { Dennis CL. } \\
2010\end{array}$ & $\begin{array}{l}\text { Postpartum } \\
\text { depression peer } \\
\text { support: maternal } \\
\text { perceptions from a } \\
\text { randomized } \\
\text { controlled trial. }\end{array}$ & $\mathrm{RCT}$ & $\begin{array}{l}\text { Adult mothers, } \\
\text { mean age } \\
30.9 \text { years, } \\
\text { baseline score } \\
\text { on EPDS <9, } \\
701 \text { subjects }\end{array}$ & $\begin{array}{l}\text { Usual } \\
\text { postpartum care } \\
\text { plus telephone- } \\
\text { based peer } \\
\text { support, a } \\
\text { minimum of four } \\
\text { contacts and } \\
\text { then interactions } \\
\text { as deemed } \\
\text { necessary } \\
\text { (provision of } \\
\text { emotional, } \\
\text { informational, } \\
\text { and appraisal } \\
\text { support), mean } \\
\text { of } 8.8 \text { contacts } \\
\text { with their peer } \\
\text { volunteers }\end{array}$ & $\begin{array}{l}\text { Usual } \\
\text { postpartum care }\end{array}$ & $\begin{array}{l}\text { Maternal } \\
\text { perceptions of } \\
\text { peer support were } \\
\text { evaluated at } 12 \\
\text { weeks postpartum } \\
\text { using PSEl } \\
\text { (supportive } \\
\text { interactions, } \\
\text { relationship } \\
\text { qualities, } \\
\text { perceived benefits, } \\
\text { satisfaction with } \\
\text { support), EPDS }\end{array}$ & $\begin{array}{l}\text { Significantly lower } \\
\text { EPDS at } 12 \text { weeks in } \\
\text { intervention group } \\
\text { (no effect at } 24 \\
\text { weeks) }(p<0.001) \text { in } \\
\text { the domains Life is } \\
\text { more enjoyable }(r= \\
0.41) \text {, Less } \\
\text { depressed }(r=0.62)\end{array}$ \\
\hline $\begin{array}{l}\text { Lara et al. } \\
2010\end{array}$ & $\begin{array}{l}\text { Outcome results of } \\
\text { a psycho- } \\
\text { educational } \\
\text { intervention in } \\
\text { pregnancy to } \\
\text { prevent PPD: a } \\
\text { randomized control } \\
\text { trial. }\end{array}$ & $\mathrm{RCT}$ & $\begin{array}{l}\text { Adult } \\
\text { pregnant with } \\
\leq 26 \text { weeks } \\
\text { gestation, } \\
\text { mean age } \\
26.9 \text { years, } \\
\text { baseline } \\
\text { depression } \\
\text { score on CES- } \\
\text { D > } 16 \text { or self- } \\
\text { reported } \\
\text { history of } \\
\text { depression, } \\
138 \text { subjects }\end{array}$ & $\begin{array}{l}\text { Psycho- } \\
\text { educational } \\
\text { manual with } 3 \\
\text { components: } \\
\text { educational, } \\
\text { psychological, } \\
\text { group } \\
\text { component, 2-h, } \\
8 \text { weekly group } \\
\text { counseling } \\
\text { sessions }\end{array}$ & $\begin{array}{l}\text { Usual } \\
\text { postpartum care }\end{array}$ & $\begin{array}{l}\text { Primary outcome: } \\
\text { major depression } \\
\text { by using SCID, } \\
\text { depressive } \\
\text { symptoms by } \\
\text { using BDI-II, } \\
\text { outcomes were } \\
\text { collected at } \\
\text { baseline, 6-weeks } \\
\text { and 4-6 month } \\
\text { postpartum }\end{array}$ & $\begin{array}{l}\text { Significantly fewer } \\
\text { new depression } \\
\text { cases in the } \\
\text { intervention group } \\
\text { ( } p<0.05 \text { ) } \\
\text { Main effect for } \\
\text { treatment and for } \\
\text { initial CES-D level } \\
\text { was significant } \\
\text { ( } p=0.54) \text {, but } \\
\text { interaction between } \\
\text { initial level of } \\
\text { symptoms and } \\
\text { treatment was not } \\
\text { significant } \\
\text { Within groups } \\
\text { significant effects of } \\
\text { time ( } p=0.00 \text { ), } \\
\text { interaction between } \\
\text { time by initial level } \\
\text { of depression } \\
\text { ( } p=0.00) \text {, time by } \\
\text { treatment ( } p=0.02 \text { ), } \\
\text { and time by } \\
\text { treatment by initial } \\
\text { level of depression } \\
\text { ( } p=0.04 \text { ) }\end{array}$ \\
\hline
\end{tabular}




\begin{tabular}{|c|c|c|c|c|c|c|c|}
\hline Author(s)/year & Study title & $\begin{array}{l}\text { Study } \\
\text { design }\end{array}$ & $\begin{array}{l}\text { Sample } \\
\text { characteristics }\end{array}$ & Intervention & Control & Outcome & Findings \\
\hline $\begin{array}{l}\text { Brugha et al. } \\
2011\end{array}$ & $\begin{array}{l}\text { Universal } \\
\text { prevention of } \\
\text { depression in } \\
\text { women postnatally: } \\
\text { cluster randomized } \\
\text { trial evidence in } \\
\text { primary care }\end{array}$ & $\mathrm{RCT}$ & $\begin{array}{l}\text { Adult } \\
\text { pregnant, } \\
\text { mean age } \\
31.8 \text { years, } \\
\text { EPDS score } \\
<12 \text { at } 6 \\
\text { weeks } \\
\text { postnatally, } \\
2241 \text { subjects }\end{array}$ & $\begin{array}{l}\text { Psychologically } \\
\text { orientated } \\
\text { sessions based } \\
\text { on CBT or } \\
\text { person-centered } \\
\text { principles, 1-h, } \\
\text { maximum } 8 \\
\text { weekly sessions }\end{array}$ & $\begin{array}{l}\text { Usual } \\
\text { postpartum care }\end{array}$ & $\begin{array}{l}\text { Primary outcome: } \\
\text { proportion of } \\
\text { women scoring } \\
\geqslant 12 \text { on the EPDS } \\
\text { at } 6 \text { months } \\
\text { postnatally, } \\
\text { Secondary } \\
\text { outcomes: mean } \\
\text { EPDS score, } \\
\text { CORE-OM score, } \\
\text { STAI, SF-12 and } \\
\text { PSI-SF scores at 6, } \\
12 \text { and } 18 \text { months }\end{array}$ & $\begin{array}{l}\text { Significantly less } \\
\text { women in } \\
\text { intervention group } \\
\text { scoring } \geqslant 12 \text { on the } \\
\text { EPDS at } 6 \text { months } \\
\text { postpartum } \\
\text { compared to control } \\
\text { group ( } p=0.016 \text { ) } \\
\text { Significant predictor } \\
\text { of the EPDS at } 6 \\
\text { months were the } \\
\text { covariates living } \\
\text { alone, previous } \\
\text { postnatal } \\
\text { depression, the } \\
\text { presence of one or } \\
\text { more adverse life } \\
\text { events and the } 6- \\
\text { week EPDS score } \\
\text { ( } p=0.031 \text { ) }\end{array}$ \\
\hline $\begin{array}{l}\text { Lewis et al. } \\
2012\end{array}$ & $\begin{array}{l}\text { Examination of a } \\
\text { Telephone-Based } \\
\text { Exercise } \\
\text { Intervention for the } \\
\text { Prevention of } \\
\text { Postpartum } \\
\text { Depression: Design, } \\
\text { Methodology, and } \\
\text { Baseline Data } \\
\text { from The Healthy } \\
\text { Mom Study }\end{array}$ & $\mathrm{RCT}$ & $\begin{array}{l}\text { Adult mothers } \\
\text { with a history } \\
\text { of depression } \\
\text { or a maternal } \\
\text { family history } \\
\text { of depression, } \\
\text { mean age } \\
31.5 \text { years, not } \\
\text { exercising, } \\
130 \text { subjects }\end{array}$ & $\begin{array}{l}\text { Telephone-based } \\
\text { exercise } \\
\text { intervention } \\
\text { including } \\
\text { telephone } \\
\text { counseling } \\
\text { sessions, } \\
\text { motivational } \\
\text { print materials, } \\
\text { and completion } \\
\text { of exercise logs, } \\
6 \text { months }\end{array}$ & $\begin{array}{l}\text { Wellness/support } \\
\text { contact control } \\
\text { condition } \\
\text { including } \\
\text { counselor only } \\
\text { providing support } \\
\text { for general } \\
\text { issues related to } \\
\text { health and } \\
\text { wellness and not } \\
\text { information } \\
\text { regarding } \\
\text { exercise, print- } \\
\text { based mailings } \\
\text { on various topics } \\
\text { related to } \\
\text { wellness, } 6 \\
\text { months }\end{array}$ & $\begin{array}{l}\text { Primary outcome: } \\
\text { depression by } \\
\text { using SCID, } \\
\text { Secondary } \\
\text { outcome: scores } \\
\text { on EPS, PHQ-9, } \\
\text { PSQI, PSS }\end{array}$ & $\begin{array}{l}\text { No significant } \\
\text { differences between } \\
\text { the PHQ-9 }(p=0.09) \text {, } \\
\text { PSS ( } p=0.87) \text {, and } \\
\text { PSQI ( } p=0.995) \\
\text { between participants } \\
\text { in the two groups } \\
\text { Three baseline } \\
\text { measures were all } \\
\text { correlated with one } \\
\text { another: PHQ-9 } \\
\text { scores were } \\
\text { significantly } \\
\text { correlated with the } \\
\text { PSS scores } \\
\text { ( } p<0.0001) \text { and PSQI } \\
\text { scores, }(p<0.0001)\end{array}$ \\
\hline $\begin{array}{l}\text { Mao et al. } \\
2012\end{array}$ & $\begin{array}{l}\text { Effectiveness of } \\
\text { Antenatal } \\
\text { Emotional Self- } \\
\text { Management } \\
\text { Training Program in } \\
\text { Prevention of } \\
\text { Postnatal } \\
\text { Depression in } \\
\text { Chinese Women }\end{array}$ & $\mathrm{RCT}$ & $\begin{array}{l}\text { Primiparous } \\
\text { pregnant } \\
\text { females, } \\
\text { mean age } \\
28.6 \text { years, } \\
240 \text { subjects }\end{array}$ & $\begin{array}{l}\text { Emotional self- } \\
\text { management } \\
\text { group training } \\
\text { (ESMGT) } \\
\text { program, based } \\
\text { on CBT with } \\
\text { elements of } \\
\text { Chinese culture } \\
\text { of delivery, 90- } \\
\text { min, } 4 \text { weekly } \\
\text { group sessions } \\
\text { and } 1 \text { individual } \\
\text { counseling } \\
\text { session }\end{array}$ & $\begin{array}{l}\text { Usual antenatal } \\
\text { care (childbirth } \\
\text { education } \\
\text { sessions), 90- } \\
\text { min, } 4 \text { times }\end{array}$ & $\begin{array}{l}\text { Depressive } \\
\text { symptoms were } \\
\text { assessed before } \\
\text { and after the } \\
\text { intervention and } 6 \\
\text { weeks after } \\
\text { delivery by using } \\
\text { PHQ-9, EPDS, } \\
\text { SCID }\end{array}$ & $\begin{array}{l}\text { Significantly lower } \\
\text { mean scores for } \\
\text { PHQ-9 }(p<0.01) \text {, } \\
\text { EPDS }(p<0.05) \text { and } \\
\text { SCID }(p<0.05) \text { in } \\
\text { intervention group } \\
\text { compared to control } \\
\text { group }\end{array}$ \\
\hline $\begin{array}{l}\text { Songøygard et } \\
\text { al. } 2012\end{array}$ & $\begin{array}{l}\text { Does exercise } \\
\text { during pregnancy } \\
\text { prevent postnatal } \\
\text { depression?: A } \\
\text { randomized } \\
\text { controlled trial. }\end{array}$ & $\mathrm{RCT}$ & $\begin{array}{l}\text { Adult } \\
\text { pregnant, } \\
\text { mean age } \\
30.5 \text { years, } \\
719 \text { subjects }\end{array}$ & $\begin{array}{l}\text { 12-week exercise } \\
\text { program } \\
\text { (including } \\
\text { aerobic and } \\
\text { strengthening), } \\
\text { exercise groups } \\
\text { once weekly for } \\
60 \text {-min, 45-min } \\
\text { home exercise } \\
\text { program at least } \\
\text { twice a week } \\
\text { (endurance } \\
\text { training and } \\
\text { strength/balance } \\
\text { exercises), } \\
\text { conducted } \\
\text { between week } 20 \\
\text { and } 36 \text { of } \\
\text { pregnancy }\end{array}$ & $\begin{array}{l}\text { Usual antenatal } \\
\text { care }\end{array}$ & $\begin{array}{l}\text { Primary outcome: } \\
\text { depressive } \\
\text { symptoms at } 3 \\
\text { months } \\
\text { postpartum by } \\
\text { using EPDS }\end{array}$ & $\begin{array}{l}\text { No significant } \\
\text { difference in total } \\
\text { EPDS scores } \\
\text { between the } \\
\text { intervention and the } \\
\text { control group } \\
(p=0.35) \\
\text { A subgroup of } \\
\text { women in the } \\
\text { intervention group } \\
\text { who did not exercise } \\
\text { regularly prior to } \\
\text { pregnancy had a } \\
\text { reduced risk of } \\
\text { postnatal } \\
\text { depression ( } p<0.05)\end{array}$ \\
\hline
\end{tabular}




\begin{tabular}{|c|c|c|c|c|c|c|c|}
\hline Author(s)/year & Study title & $\begin{array}{l}\text { Study } \\
\text { design }\end{array}$ & $\begin{array}{l}\text { Sample } \\
\text { characteristics }\end{array}$ & Intervention & Control & Outcome & Findings \\
\hline $\begin{array}{l}\text { Kozinszky et } \\
\text { al. } 2012\end{array}$ & $\begin{array}{l}\text { Can a brief } \\
\text { antepartum } \\
\text { preventive group } \\
\text { intervention help } \\
\text { reduce postpartum } \\
\text { depressive } \\
\text { symptomatology? }\end{array}$ & RCT & $\begin{array}{l}\text { All pregnant } \\
\text { women living } \\
\text { in catchment } \\
\text { area were } \\
\text { approached, } \\
\text { mean age } \\
27.3 \text { years, } \\
1719 \text { subjects }\end{array}$ & $\begin{array}{l}\text { Group sessions } \\
\text { consisting of } \\
\text { psychoeducation } \\
\text { and } \\
\text { psychotherapy } \\
\text { for PPD utilizing } \\
\text { group therapy, } \\
\text { interpersonal } \\
\text { psychotherapy, } \\
\text { and CBT } \\
\text { elements, 3-h, } \\
\text { once weekly, } 4 \\
\text { times }\end{array}$ & $\begin{array}{l}\text { Treatment as } \\
\text { usual but in } \\
\text { group meetings, } \\
\text { once weekly, } 4 \\
\text { times }\end{array}$ & $\begin{array}{l}\text { Primary outcome: } \\
\text { depressive } \\
\text { symptoms by } \\
\text { using LQ, } 4 \text { times } \\
\text { during pregnancy } \\
\text { and } 6 \text { weeks } \\
\text { postpartum }\end{array}$ & $\begin{array}{l}\text { Significant lower LQ } \\
\text { scores }(p<0.001) \\
\text { and PPD } \\
\text { prevalences }(p<0.01) \\
6 \text { weeks postpartum } \\
\text { in the intervention } \\
\text { group than the } \\
\text { control group }\end{array}$ \\
\hline $\begin{array}{l}\text { Mozurkewich } \\
\text { et al. } 2013\end{array}$ & $\begin{array}{l}\text { The Mothers, } \\
\text { Omega-3, and } \\
\text { Mental Health } \\
\text { Study: a double- } \\
\text { blind, randomized } \\
\text { controlled trial }\end{array}$ & $\mathrm{RCT}$ & $\begin{array}{l}\text { Adult } \\
\text { pregnant with } \\
12-20 \text { weeks } \\
\text { gestation, } \\
\text { mean age } \\
30.3 \text { years, } \\
\text { baseline EPDS } \\
\text { score } 9-19 \text {, } \\
\text { history of } \\
\text { depression, } \\
\text { currently not } \\
\text { taking omega- } \\
3 \text { fatty acid } \\
\text { supplements } \\
\text { or eating more } \\
\text { than } 2 \text { fish } \\
\text { meals per } \\
\text { week, } 126 \\
\text { subjects }\end{array}$ & $\begin{array}{l}\text { EPA-rich (1060 } \\
\text { mg EPA plus } 274 \\
\text { mg DHA) fish oil } \\
\text { supplementation } \\
\text { or DHA-rich ( } 900 \\
\text { mg DHA plus } \\
180 \text { mg EPA) fish } \\
\text { oil supplement, } 6 \\
\text { capsules twice } \\
\text { daily, } 3 \text { months }\end{array}$ & $\begin{array}{l}\text { Soy oil placebo, } 6 \\
\text { capsules twice } \\
\text { daily, } 3 \text { months }\end{array}$ & $\begin{array}{l}\text { BDI and Mini- } \\
\text { International } \\
\text { Neuropsychiatric } \\
\text { Interview at } \\
\text { enrollment, 26-28 } \\
\text { weeks, 34-36 } \\
\text { weeks, and at 6-8 } \\
\text { weeks' } \\
\text { postpartum, } \\
\text { serum fatty acids } \\
\text { were analyzed at } \\
\text { entry and at 34- } \\
36 \text { weeks' } \\
\text { gestation }\end{array}$ & $\begin{array}{l}\text { No differences } \\
\text { between groups in } \\
\text { BDI scores or other } \\
\text { depression } \\
\text { endpoints at any of } \\
\text { the } 3 \text { time points } \\
\text { after } \\
\text { supplementation } \\
\text { (Significance=0.051) } \\
\text { DHA levels did } \\
\text { predict BDI score at } \\
34-36 \text { weeks } \\
(p<0.05)\end{array}$ \\
\hline $\begin{array}{l}\text { Dugravier et } \\
\text { al. } 2013\end{array}$ & $\begin{array}{l}\text { Impact of a } \\
\text { Manualized } \\
\text { Multifocal Perinatal } \\
\text { Home-Visiting } \\
\text { Program Using } \\
\text { Psychologists on } \\
\text { Postnatal } \\
\text { Depression: The } \\
\text { CAPEDP } \\
\text { Randomized } \\
\text { Controlled Trial }\end{array}$ & $\mathrm{RCT}$ & $\begin{array}{l}\text { Primiparous } \\
\text { pregnant } \\
\text { females with } \\
12 \text { to } 27 \\
\text { weeks } \\
\text { gestation, less } \\
\text { than } 26 \text { years } \\
\text { old, at least } \\
\text { one of the } \\
\text { following } \\
\text { criteria: } 1) \\
\text { having less } \\
\text { than twelve } \\
\text { years of } \\
\text { education, } 2 \text { ) } \\
\text { planning to } \\
\text { bring up their } \\
\text { child without } \\
\text { the child's } \\
\text { father, } 3 \text { ) } \\
\text { having low } \\
\text { income; mean } \\
\text { age } 22.3 \\
\text { years, } 367 \\
\text { subjects }\end{array}$ & $\begin{array}{l}\text { CAPEDP: } 14 \\
\text { intensive } \\
\text { multifocal home } \\
\text { visits done by } \\
\text { psychologists } \\
\text { who promoted } \\
\text { perinatal mental } \\
\text { and physical } \\
\text { health, identified } \\
\text { depressive } \\
\text { symptoms, } \\
\text { provided support } \\
\text { and referred to } \\
\text { care if necessary, } \\
12 \text { months, 27- } \\
\text { month follow-up }\end{array}$ & $\begin{array}{l}\text { Usual } \\
\text { postpartum care }\end{array}$ & $\begin{array}{l}\text { Primary outcome: } \\
\text { depressive } \\
\text { symptoms by } \\
\text { using EPDS at } \\
\text { baseline and } 3 \\
\text { months } \\
\text { postpartum }\end{array}$ & $\begin{array}{l}\text { No overall impact on } \\
\text { postnatal } \\
\text { depression } \\
\text { symptomatology } \\
\text { Intervention was } \\
\text { effective in reducing } \\
\text { levels of PPD for } \\
\text { subgroups: women } \\
\text { who had few } \\
\text { depressive } \\
\text { symptoms at } \\
\text { baseline ( } p=0.05 \text { ), } \\
\text { women who were } \\
\text { planning to raise the } \\
\text { child with the child's } \\
\text { father ( } p=0.04 \text { ) and } \\
\text { women with a higher } \\
\text { educational level } \\
\text { ( } p=0.05 \text { ) }\end{array}$ \\
\hline
\end{tabular}




\begin{tabular}{|c|c|c|c|c|c|c|c|}
\hline Author(s)/year & Study title & $\begin{array}{l}\text { Study } \\
\text { design }\end{array}$ & $\begin{array}{l}\text { Sample } \\
\text { characteristics }\end{array}$ & Intervention & Control & Outcome & Findings \\
\hline $\begin{array}{l}\text { Moshki et al. } \\
2014\end{array}$ & $\begin{array}{l}\text { The effect of } \\
\text { educational } \\
\text { intervention on } \\
\text { prevention of } \\
\text { postpartum } \\
\text { depression: An } \\
\text { application of } \\
\text { health locus of } \\
\text { control }\end{array}$ & RCT & $\begin{array}{l}\text { Pregnant } \\
\text { females with } \\
28-30 \text { weeks } \\
\text { gestation, } \\
\text { mean age } \\
27.9 \text { years, } \\
230 \text { subjects }\end{array}$ & $\begin{array}{l}\text { Participatory } \\
\text { educational } \\
\text { program: } \\
\text { information } \\
\text { about anatomic } \\
\text { and } \\
\text { physiological } \\
\text { changes, } \\
\text { nutrition, } \\
\text { common } \\
\text { complications } \\
\text { during } \\
\text { pregnancy, } \\
\text { mental health } \\
\text { and } \\
\text { communication } \\
\text { skills, } \\
\text { familiarization } \\
\text { with pregnancy } \\
\text { stages, delivery } \\
\text { and pain } \\
\text { reduction } \\
\text { methods, } \\
\text { postpartum } \\
\text { health, emotions } \\
\text { and attitudes of } \\
\text { women with } \\
\text { special } \\
\text { emphasis on } \\
\text { components of } \\
\text { HLC including } \\
\text { internal HLC, } \\
\text { powerful others } \\
\text { HLC, chance } \\
\text { HLC, } 36 \text { hours in } \\
\text { total, } 9 \\
\text { workshops }\end{array}$ & $\begin{array}{l}\text { Usual } \\
\text { postpartum care }\end{array}$ & $\begin{array}{l}\text { Primary outcome: } \\
\text { health behaviors } \\
\text { according to } \\
\text { participants' } \\
\text { beliefs by using } \\
\text { MHLCS } \\
\text { immediately after } \\
\text { the intervention } \\
\text { sessions, } \\
\text { depressive } \\
\text { symptoms by } \\
\text { using EPDS after } \\
\text { four weeks } \\
\text { postpartum }\end{array}$ & $\begin{array}{l}\text { Significantly } \\
\text { reduced chance HLC } \\
\text { ( } p=0.003 \text { ) and } \\
\text { internal HLC } \\
\text { ( } p=0.03 \text { ) } \\
\text { significantly } \\
\text { increased } \\
\text { immediately after } \\
\text { intervention } \\
\text { Significant } \\
\text { difference between } \\
\text { the two groups in } \\
\text { reducing postpartum } \\
\text { depression one } \\
\text { month after } \\
\text { intervention } \\
\text { ( } p=0.001) \\
\text { Significant } \\
\text { correlation between } \\
\text { internal belief } \\
\text { ( } p<0.05 \text { ) and chance } \\
\text { belief }(p<0.01 \text { ) with } \\
\text { EPDS }\end{array}$ \\
\hline $\begin{array}{l}\text { Hiscock et al. } \\
2014\end{array}$ & $\begin{array}{l}\text { Preventing Early } \\
\text { Infant Sleep and } \\
\text { Crying Problems } \\
\text { and Postnatal } \\
\text { Depression: A } \\
\text { Randomized Trial }\end{array}$ & RCT & $\begin{array}{l}\text { Families with } \\
\text { infants }>32 \\
\text { weeks } \\
\text { gestation, } \\
\text { mean age } \\
\text { caregiver } \\
33.15 \text { years, } \\
781 \text { infants }\end{array}$ & $\begin{array}{l}\text { Prevention } \\
\text { program for } \\
\text { infant sleep and } \\
\text { cry problems and } \\
\text { postnatal } \\
\text { depression } \\
\text { including } \\
\text { supplying } \\
\text { information } \\
\text { about normal } \\
\text { infant sleep and } \\
\text { cry patterns, } \\
\text { settling } \\
\text { techniques, } \\
\text { medical causes } \\
\text { of crying and } \\
\text { parent self-care, } \\
\text { delivered via } \\
\text { booklet and DVD } \\
\text { (at infant age } 4 \\
\text { weeks), } \\
\text { telephone } \\
\text { consultation (8 } \\
\text { weeks), parent } \\
\text { group sessions } \\
\text { (13 weeks); } \\
\text { follow-up at } \\
\text { infant age 4- and } \\
6 \text {-months }\end{array}$ & Usual childcare & $\begin{array}{l}\text { EPDS, sleep } \\
\text { quality and } \\
\text { quantity, } \\
\text { breastfeeding } \\
\text { duration }\end{array}$ & $\begin{array}{l}\text { No group } \\
\text { differences in } \\
\text { caregiver reports of } \\
\text { depression } \\
\text { symptoms at } 4 \\
\text { months }(p=0.07) \\
\text { Significant greater } \\
\text { reduction of } \\
\text { depressive } \\
\text { symptoms in the } \\
\text { intervention } \\
\text { caregivers at } 6 \\
\text { months }(p=0.03)\end{array}$ \\
\hline
\end{tabular}




\begin{tabular}{|c|c|c|c|c|c|c|c|}
\hline Author(s)/year & Study title & $\begin{array}{l}\text { Study } \\
\text { design }\end{array}$ & $\begin{array}{l}\text { Sample } \\
\text { characteristics }\end{array}$ & Intervention & Control & Outcome & Findings \\
\hline $\begin{array}{l}\text { Nugent et al. } \\
2014\end{array}$ & $\begin{array}{l}\text { Effects of an Infant- } \\
\text { focused } \\
\text { Relationship-based } \\
\text { Hospital and Home } \\
\text { Visiting Intervention } \\
\text { on Reducing } \\
\text { Symptoms of } \\
\text { Postpartum } \\
\text { Maternal } \\
\text { Depression: A Pilot } \\
\text { Study }\end{array}$ & RCT & $\begin{array}{l}\text { First-time } \\
\text { mothers } \\
\text { cohabitating } \\
\text { with the father } \\
\text { of the baby, } \\
\text { vaginal } \\
\text { delivery of an } \\
\text { infant } \\
\text { between 36- } \\
\text { and } 42 \text {-weeks } \\
\text { gestational } \\
\text { age, Apgar } \\
\text { scores not } \\
\text { less than } 7 \text {, } \\
\text { mean age } 28 \\
\text { years, } 104 \\
\text { subjects }\end{array}$ & $\begin{array}{l}\text { Routine care plus } \\
\text { Newborn } \\
\text { Behavioral } \\
\text { Observations } \\
\text { (NBO) within two } \\
\text { days post- } \\
\text { delivery (in } \\
\text { hospital) and } \\
\text { one-month } \\
\text { postpartum } \\
\text { (home visit), } 18 \\
\text { NBO of the } \\
\text { infant's } \\
\text { behavioral } \\
\text { repertoire along } \\
\text { four dimensions } \\
\text { (autonomic, } \\
\text { motor, state } \\
\text { organization and } \\
\text { attentional- } \\
\text { interactional), } 12 \\
\text { to } 25 \text { minutes }\end{array}$ & $\begin{array}{l}\text { Usual } \\
\text { postpartum care } \\
\text { and short } \\
\text { attention-control } \\
\text { home visit to } \\
\text { administer the } \\
\text { EPDS }\end{array}$ & $\begin{array}{l}\text { Primary outcome: } \\
\text { depressive } \\
\text { symptoms at } 1 \\
\text { month } \\
\text { postpartum using } \\
\text { EPDS }\end{array}$ & $\begin{array}{l}\text { Significantly fewer } \\
\text { mothers had } \\
\text { elevated depression } \\
\text { scores in the } \\
\text { intervention group } \\
(p=0.05)\end{array}$ \\
\hline $\begin{array}{l}\text { Maimburg et } \\
\text { al. } 2015\end{array}$ & $\begin{array}{l}\text { Postpartum } \\
\text { depression among } \\
\text { first-time mothers - } \\
\text { results from a } \\
\text { parallel randomised } \\
\text { trial }\end{array}$ & $\mathrm{RCT}$ & $\begin{array}{l}\text { Nulliparous } \\
\text { adult pregnant } \\
\text { females } \\
\text { between } 10+ \\
0 \text { to } 21+6 \\
\text { days of } \\
\text { gestation, } \\
\text { singleton } \\
\text { pregnancy, } \\
\text { mean age } \\
29.3 \text { years, } \\
1062 \text { subjects }\end{array}$ & $\begin{array}{l}\text { "The Ready for } \\
\text { Child" antenatal } \\
\text { education } \\
\text { program, } \\
\text { between the 30th } \\
\text { - 35th weeks of } \\
\text { gestation: } \\
\text { content of the } \\
\text { birth module, the } \\
\text { newborn module } \\
\text { and the parent } \\
\text { module with } \\
\text { information } \\
\text { about PPD } \\
\text { (information on } \\
\text { prevalence, } \\
\text { prevention, } \\
\text { symptoms } \\
\text { (shared and } \\
\text { different } \\
\text { symptoms in } \\
\text { men and } \\
\text { women), and } \\
\text { PPD treatment), } \\
3 \text { modules of } 3 \\
\text { hours }\end{array}$ & $\begin{array}{l}\text { Usual antenatal } \\
\text { care }\end{array}$ & $\begin{array}{l}\text { Primary } \\
\text { outcomes: } \\
\text { demographics, } \\
\text { depressive } \\
\text { symptoms using } \\
\text { EPDS at } 6 \text { weeks } \\
\text { postpartum and } \\
\text { identifying risk } \\
\text { factors for PPD }\end{array}$ & $\begin{array}{l}\text { No significant } \\
\text { difference in EPDS } \\
\text { at } 6 \text { weeks } \\
\text { postpartum between } \\
\text { the two groups }\end{array}$ \\
\hline $\begin{array}{l}\text { Dimidjian et } \\
\text { al. } 2016\end{array}$ & $\begin{array}{l}\text { Staying Well during } \\
\text { Pregnancy and the } \\
\text { Postpartum: A Pilot } \\
\text { Randomized Trial } \\
\text { of Mindfulness } \\
\text { Based Cognitive } \\
\text { Therapy for the } \\
\text { Prevention of } \\
\text { Depressive } \\
\text { Relapse/Recurrence }\end{array}$ & RCT & $\begin{array}{l}\text { Adult } \\
\text { pregnant } \\
\text { females with } \\
\text { >32 weeks } \\
\text { gestation, } \\
\text { meeting } \\
\text { criteria for } \\
\text { prior major } \\
\text { depressive } \\
\text { disorder } \\
\text { (MDD), } \\
\text { exclusion if } \\
\text { diagnosis of } \\
\text { MDD in the } \\
\text { last two } \\
\text { months, mean } \\
\text { age 29.85 } \\
\text { years, } 86 \\
\text { subjects }\end{array}$ & $\begin{array}{l}\text { MBCT-PD, at- } \\
\text { home practice } \\
\text { for } 6 \text { days each } \\
\text { week, } 42 \text { days in } \\
\text { total }\end{array}$ & $\begin{array}{l}\text { Usual antenatal } \\
\text { care }\end{array}$ & $\begin{array}{l}\text { Primary outcome: } \\
\text { baseline } \\
\text { diagnostic status } \\
\text { via SCID-I/P and } \\
\text { SCID-II } \\
\text { Depression } \\
\text { relapse/recurrence } \\
\text { using LIFE at 8- } \\
\text { weeks, } 1 \text { month } \\
\text { prior to delivery } \\
\text { and } 1 \text { and } 6 \\
\text { months } \\
\text { postpartum; } \\
\text { Depression } \\
\text { symptom severity } \\
\text { using EPDS }\end{array}$ & $\begin{array}{l}\text { Significant } \\
\text { difference in the rate } \\
\text { of } \\
\text { relapse/recurrence } \\
\text { between intervention } \\
\text { and control group } \\
\text { ( } p=0.005 \text { ) in the } \\
\text { postpartum period } \\
\text { Significantly lower } \\
\text { levels of depressive } \\
\text { severity in } \\
\text { intervention than in } \\
\text { control group } \\
(p=0.002)\end{array}$ \\
\hline
\end{tabular}




\begin{tabular}{|c|c|c|c|c|c|c|c|}
\hline Author(s)/year & Study title & $\begin{array}{l}\text { Study } \\
\text { design }\end{array}$ & $\begin{array}{l}\text { Sample } \\
\text { characteristics }\end{array}$ & Intervention & Control & Outcome & Findings \\
\hline $\begin{array}{l}\text { Werner et al. } \\
2016\end{array}$ & $\begin{array}{l}\text { PREPP: Postpartum } \\
\text { Depression } \\
\text { Prevention through } \\
\text { the Mother-Infant } \\
\text { Dyad }\end{array}$ & RCT & $\begin{array}{l}\text { Pregnant } \\
\text { females in } \\
\text { 2nd or 3rd } \\
\text { trimester of } \\
\text { pregnancy, } \\
\text { Predictive } \\
\text { Index of } \\
\text { Postnatal } \\
\text { Depression } \\
\text { score > 24, } \\
\text { aged 18-45 } \\
\text { years, mean } \\
\text { age } 30.22 \\
\text { years, } 54 \\
\text { subjects }\end{array}$ & $\begin{array}{l}3 \text { PREPP } \\
\text { sessions } \\
\text { covering: five } \\
\text { specific infant } \\
\text { behavioral } \\
\text { techniques } \\
\text { (feeding, day- } \\
\text { night rhythm, } \\
\text { carrying } \\
\text { duration, } \\
\text { swaddling) } \\
\text { Supportive } \\
\text { psychological } \\
\text { interviewing } \\
\text { (using } \\
\text { Motivational } \\
\text { Interviewing } \\
\text { techniques) } \\
\text { Psychoeducation } \\
\text { Mindfulness } \\
\text { techniques }\end{array}$ & $\begin{array}{l}\text { Enhanced } \\
\text { treatment as } \\
\text { usual and } 2 \\
\text { meetings with } \\
\text { psychologists } \\
\text { (34-38 weeks } \\
\text { gestation and } 6 \\
\text { weeks } \\
\text { postpartum): } \\
\text { participants were } \\
\text { provided with } \\
\text { information } \\
\text { about PPD and } \\
\text { referral for } \\
\text { treatment if } \\
\text { warranted }\end{array}$ & $\begin{array}{l}\text { Primary outcome: } \\
\text { predictive index of } \\
\text { PPD (PPD risk = } \\
\text { >24), indexes } \\
\text { depressive } \\
\text { symptoms via } \\
\text { HRSD and PHQ-9 }\end{array}$ & $\begin{array}{l}\text { Significantly } \\
\text { decreased } \\
\text { depressive } \\
\text { symptoms in } \\
\text { intervention group in } \\
\text { contrast to control } \\
\text { group }(p=0.01 \text { ) at } \\
36-38 \text { weeks } \\
\text { gestation and } 6 \\
\text { weeks postpartum } \\
\text { Significantly more } \\
\text { depressive } \\
\text { symptoms at } 6 \\
\text { weeks postpartum in } \\
\text { control group in } \\
\text { contrast to } \\
\text { intervention group } \\
\text { (p=0.02) }\end{array}$ \\
\hline $\begin{array}{l}\text { Tsai et al. } \\
2016\end{array}$ & $\begin{array}{l}\text { Food Insufficiency, } \\
\text { Depression, and the } \\
\text { Modifying Role of } \\
\text { Social Support: } \\
\text { Evidence from a } \\
\text { Population-Based, } \\
\text { Prospective Cohort } \\
\text { of Pregnant Women } \\
\text { in Peri-Urban South } \\
\text { Africa }\end{array}$ & $\mathrm{RCT}$ & $\begin{array}{l}\text { All pregnant } \\
\text { females living } \\
\text { in study } \\
\text { catchment } \\
\text { area who were } \\
\text { willing to } \\
\text { participate, } \\
958 \text { subjects }\end{array}$ & $\begin{array}{l}\text { Home visiting } \\
\text { intervention: } \\
\text { problem-solving } \\
\text { and cognitive- } \\
\text { behavioral } \\
\text { techniques to } \\
\text { address major } \\
\text { community } \\
\text { health } \\
\text { challenges (HIV, } \\
\text { tuberculosis, } \\
\text { malnutrition, } \\
\text { alcohol use), } 4 \\
\text { visits and follow- } \\
\text { up }\end{array}$ & $\begin{array}{l}\text { Standard clinic } \\
\text { care groups } \\
\text { generally } \\
\text { consisted of } \\
\text { tuberculosis and } \\
\text { HIV testing, } \\
\text { partner HIV } \\
\text { testing, } \\
\text { antiretroviral } \\
\text { therapy, } \\
\text { antenatal and } \\
\text { postnatal care, } \\
\text { well-child clinics, } \\
\text { and primary } \\
\text { health care }\end{array}$ & $\begin{array}{l}\text { Primary outcome: } \\
\text { depression } \\
\text { symptom severity } \\
\text { measured at all } \\
\text { time points using } \\
\text { EPDS, surveys } \\
\text { were conducted at } \\
\text { baseline, } 6,18 \text {, } \\
\text { and } 36 \text { months, } \\
\text { number of days of } \\
\text { hunger in the past } \\
\text { week via single- } \\
\text { item food } \\
\text { insufficiency } \\
\text { measure; 10 } \\
\text { questions about } \\
\text { emotional and } \\
\text { instrumental } \\
\text { support, 36-month } \\
\text { follow-up } \\
\text { interview using } \\
\text { HFIAS }\end{array}$ & $\begin{array}{l}\text { Strong significant } \\
\text { association between } \\
\text { lagged food } \\
\text { insufficiency and } \\
\text { depression } \\
\text { symptom severity } \\
(\beta=0.70 ; 95 \% \mathrm{Cl} \text {, } \\
0.46-0.94) \\
\text { Significant } \\
\text { association between } \\
\text { food insufficiency } \\
\text { and depression } \\
\text { among women with } \\
\text { low levels of } \\
\text { instrumental support } \\
(\beta=0.79 ; 95 \% \mathrm{Cl} \text {, } \\
0.51-1.07)\end{array}$ \\
\hline $\begin{array}{l}\text { Lewis et al. } \\
2017\end{array}$ & $\begin{array}{l}\text { The relationship } \\
\text { between } \\
\text { employment status } \\
\text { and depression } \\
\text { symptomatology } \\
\text { among women at } \\
\text { risk for postpartum } \\
\text { depression }\end{array}$ & $\mathrm{RCT}$ & $\begin{array}{l}\text { Healthy } \\
\text { women who } \\
\text { had } \\
\text { participated in } \\
\text { a randomized } \\
\text { trial (see } \\
\text { Lewis et al. } \\
\text { 2012) and } \\
\text { had a } \\
\text { personal or } \\
\text { maternal } \\
\text { family history } \\
\text { of depression, } \\
\text { aged 18-42 } \\
\text { years, mean } \\
\text { age 30.8 } \\
\text { years, } 124 \\
\text { subjects }\end{array}$ & $\begin{array}{l}\text { Telephone-based } \\
\text { exercise } \\
\text { intervention, } 6 \\
\text { months }\end{array}$ & $\begin{array}{l}\text { Wellness/support } \\
\text { contact, } 6 \\
\text { months }\end{array}$ & $\begin{array}{l}\text { Demographic } \\
\text { questionnaire } \\
\text { (income, marital } \\
\text { status, education } \\
\text { level) } \\
\text { Telephone-based } \\
\text { interview at } \\
\text { baseline } \\
\text { (approximately } 6 \\
\text { weeks } \\
\text { postpartum): } \\
\text { race/ethnicity, } \\
\text { age, body mass } \\
\text { index, } \\
\text { antidepressant } \\
\text { use } \\
\text { Telephone-based } \\
\text { interview at } 7 \\
\text { months: } \\
\text { employment and } \\
\text { breastfeeding } \\
\text { statuses, EPDs }\end{array}$ & $\begin{array}{l}\text { Significant } \\
\text { association between } \\
\text { employment status } \\
\text { and higher } \\
\text { depression } \\
\text { symptomatology } \\
\text { ( } \mathrm{p}=0.010) \\
\text { Significant } \\
\text { association between } \\
\text { being single and } \\
\text { higher depression } \\
\text { symptomatology at } \\
7 \text { months } \\
\text { postpartum } \\
\text { ( } \mathrm{p}=0.001 \text { ) } \\
\text { No significant } \\
\text { differences between } \\
\text { women who worked } \\
\text { full- time versus } \\
\text { part-time on } \\
\text { depression } \\
\text { symptomatology } \\
\text { ( } \mathrm{r}=-0.022 \text {, ns.) }\end{array}$ \\
\hline
\end{tabular}




\begin{tabular}{|c|c|c|c|c|c|c|c|}
\hline Author(s)/year & Study title & $\begin{array}{l}\text { Study } \\
\text { design }\end{array}$ & $\begin{array}{l}\text { Sample } \\
\text { characteristics }\end{array}$ & Intervention & Control & Outcome & Findings \\
\hline Xu et al. 2017 & $\begin{array}{l}\text { Single bolus low- } \\
\text { dose of ketamine } \\
\text { does not prevent } \\
\text { postpartum } \\
\text { depression: a } \\
\text { randomized, } \\
\text { double-blind, } \\
\text { placebo-controlled, } \\
\text { prospective clinical } \\
\text { trial }\end{array}$ & $\mathrm{RCT}$ & $\begin{array}{l}\text { Pregnant } \\
\text { women who } \\
\text { were } \\
\text { scheduled to } \\
\text { undergo } \\
\text { caesarean } \\
\text { section with } \\
\text { spinal } \\
\text { anaesthesia, } \\
\text { mean age } \\
31.5,330 \\
\text { subjects }\end{array}$ & $\begin{array}{l}\text { Ketamine group: } \\
\text { subjects received } \\
\text { intravenous } \\
\text { ketamine ( } 0.25 \\
\mathrm{mg} / \mathrm{kg} \text { diluted to } \\
10 \mathrm{~mL} \text { with } 0.9 \% \\
\text { saline) within } 5 \\
\text { min following } \\
\text { clamping of the } \\
\text { neonatal } \\
\text { umbilical cord }\end{array}$ & $\begin{array}{l}\text { Saline group: } \\
\text { subjects received } \\
\text { intravenous } \\
\text { placebo ( } 10 \mathrm{~mL} \\
\text { of } 0.9 \% \text { saline) } \\
\text { within } 5 \text { min } \\
\text { following } \\
\text { clamping of the } \\
\text { neonatal } \\
\text { umbilical cord }\end{array}$ & $\begin{array}{l}\text { Primary outcome: } \\
\text { degree of } \\
\text { depression by } \\
\text { using the EPDS (a } \\
\text { threshold of } 9 / 10 \\
\text { was used) at } 3 \\
\text { days and } 6 \text { weeks } \\
\text { after delivery } \\
\text { Secondary } \\
\text { outcome: numeric } \\
\text { rating scale score } \\
\text { of pain at } 3 \text { day } \\
\text { and } 6 \text { week } \\
\text { postpartum }\end{array}$ & $\begin{array}{l}\text { No significant } \\
\text { differences in the } \\
\text { prevalence of } \\
\text { postpartum } \\
\text { depression between } \\
\text { the two groups at } 3 \\
\text { days }(p=0.965) \text { and } \\
6 \text { weeks }(p=0.900) \\
\text { after delivery }\end{array}$ \\
\hline $\begin{array}{l}\text { Duncan et al. } \\
2017\end{array}$ & $\begin{array}{l}\text { Benefits of } \\
\text { preparing for } \\
\text { childbirth with } \\
\text { mindfulness } \\
\text { training: a } \\
\text { randomized } \\
\text { controlled trial with } \\
\text { active comparison }\end{array}$ & RCT & $\begin{array}{l}\text { First-time } \\
\text { mothers in the } \\
\text { late 3rd } \\
\text { trimester of } \\
\text { singleton } \\
\text { pregnancy, no } \\
\text { extensive prior } \\
\text { experience } \\
\text { with } \\
\text { meditation or } \\
\text { yoga practice, } \\
29 \text { subjects }\end{array}$ & $\begin{array}{l}\text { Mind in Labor } \\
\text { (MIL): Working } \\
\text { with Pain in } \\
\text { Childbirth } \\
\text { (Preparation } \\
\text { course based on } \\
\text { Mindfulness- } \\
\text { Based Childbirth } \\
\text { and Parenting } \\
\text { (MBCP) } \\
\text { education, } \\
\text { subjects } \\
\text { completed self- } \\
\text { report } \\
\text { assessments } \\
\text { pre-intervention, } \\
\text { post-intervention, } \\
\text { and post-birth, } \\
\text { and medical } \\
\text { record data were } \\
\text { collected; 2.5-day } \\
\text { weekend } \\
\text { workshop }\end{array}$ & $\begin{array}{l}\text { Usual antenatal } \\
\text { care, participants } \\
\text { received a list of } \\
\text { childbirth } \\
\text { courses of } \\
\text { comparable } \\
\text { length and } \\
\text { quality to the MIL } \\
\text { intervention, but } \\
\text { without any } \\
\text { mindfulness } \\
\text { meditation, } \\
\text { mindful } \\
\text { movement/yoga, } \\
\text { or other core } \\
\text { mind/body } \\
\text { component (e.g., } \\
\text { hypnosis), they } \\
\text { were strongly } \\
\text { encouraged to } \\
\text { participate in the } \\
\text { control childbirth } \\
\text { education with a } \\
\text { support person, } \\
\text { just as with MIL }\end{array}$ & $\begin{array}{l}\text { Depression using } \\
\text { CES-D at average } \\
\text { gestational age } \\
29.4 \text { weeks, in the } \\
\text { week immediately } \\
\text { following } \\
\text { intervention, } \\
\text { within six weeks } \\
\text { after birth }\end{array}$ & $\begin{array}{l}\text { Perinatal and } \\
\text { postpartum } \\
\text { depression } \\
\text { symptoms: } \\
\text { significant } \\
\text { interaction between } \\
\text { group and time } \\
(p=0.04)\end{array}$ \\
\hline
\end{tabular}




\begin{tabular}{|c|c|c|c|c|c|c|c|}
\hline Author(s)/year & Study title & $\begin{array}{l}\text { Study } \\
\text { design }\end{array}$ & $\begin{array}{l}\text { Sample } \\
\text { characteristics }\end{array}$ & Intervention & Control & Outcome & Findings \\
\hline $\begin{array}{l}\text { Young et al. } \\
2018\end{array}$ & $\begin{array}{l}\text { Placentophagy's } \\
\text { effects on mood, } \\
\text { bonding, and } \\
\text { fatigue: A pilot trial, } \\
\text { part } 2\end{array}$ & RCT & $\begin{array}{l}\text { Adult } \\
\text { pregnant } \\
\text { females who } \\
\text { had previously } \\
\text { decided they } \\
\text { would ingest } \\
\text { their placenta } \\
\text { after birth, } \\
\text { mean age } \\
29.9 \text { years, } 27 \\
\text { subjects }\end{array}$ & $\begin{array}{l}\text { Participants } \\
\text { consumed their } \\
\text { processed, } \\
\text { encapsulated } \\
\text { placenta: two } \\
550 \text { mg capsules } \\
3 \text { times daily for } \\
\text { the first } 4 \text { days } \\
\text { of } \\
\text { supplementation, } \\
\text { decreased } \\
\text { dosage of } 2 \\
\text { capsules twice } \\
\text { daily, on days } 5 \\
\text { through } 12 \text { of } \\
\text { supplementation, } \\
\text { and reduced } \\
\text { dosage to } 2 \\
\text { capsules once } \\
\text { daily through } \\
\text { completion, } 4 \\
\text { meetings with } \\
\text { researcher }\end{array}$ & $\begin{array}{l}\text { Similarly } \\
\text { prepared } \\
\text { placebo, same } \\
\text { intake }\end{array}$ & $\begin{array}{l}\text { Primary outcome: } \\
\text { scored results of } \\
\text { the EPDS, KBQ, } \\
\text { DASS-21, FAS, } \\
\text { MIBS, and SCL-90- } \\
\text { R }\end{array}$ & $\begin{array}{l}\text { No significant main } \\
\text { effects }(p=0.016)\end{array}$ \\
\hline
\end{tabular}

\section{Figures}

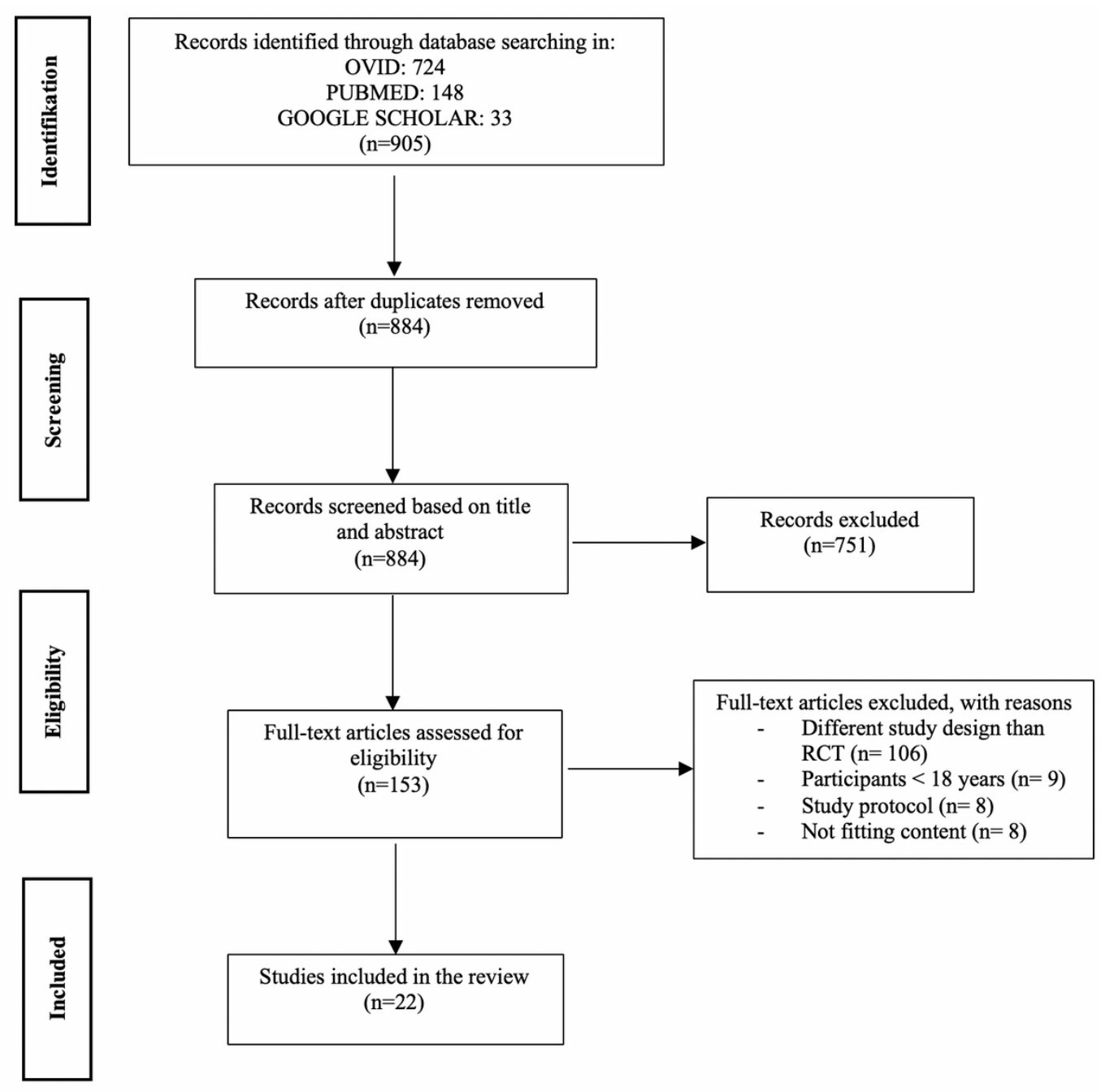

Figure 1

Flow diagram of the selection process 


\section{Supplementary Files}

This is a list of supplementary files associated with this preprint. Click to download.

- CoverLetterNM30.5.docx

- PRISMAchecklistNMBMC.doc 